Article

\title{
In Vitro Anti-Diabetic Activities and UHPLC-ESI-MS/MS Profile of Muntingia calabura Leaves Extract
}

\author{
Nur Khaleeda Zulaikha Zolkeflee ${ }^{1}\left(\mathbb{D}\right.$, Nurul Shazini Ramli ${ }^{2}$, Azrina Azlan ${ }^{3}\left(\mathbb{C}\right.$ and Faridah Abas $\left.{ }^{1,2, *} \mathbb{(}\right)$ \\ 1 Natural Medicines and Products Research Laboratory, Institute of Bioscience, Universiti Putra Malaysia, \\ Serdang 43400, Malaysia; khaleeda_zulaikha@yahoo.com \\ 2 Department of Food Science, Faculty of Food Science and Technology, Universiti Putra Malaysia, \\ Serdang 43400, Malaysia; shazini@upm.edu.my \\ 3 Department of Nutrition and Dietetics, Faculty of Medicine and Health Sciences, Universiti Putra Malaysia, \\ Serdang 43400, Malaysia; azrinaaz@upm.edu.my \\ * Correspondence: faridah_abas@upm.edu.my; Tel.: +60-3976-9834-3
}

check for updates

Citation: Zolkeflee, N.K.Z.; Ramli, N.S.; Azlan, A.; Abas, F. In Vitro

Anti-Diabetic Activities and UHPLC-ESI-MS/MS Profile of Muntingia calabura Leaves Extract. Molecules 2022, 27, 287. https: / / doi.org/10.3390/ molecules 27010287

Academic Editor: Jane Ward

Received: 16 November 2021

Accepted: 8 December 2021

Published: 4 January 2022

Publisher's Note: MDPI stays neutral with regard to jurisdictional claims in published maps and institutional affiliations.

Copyright: (c) 2022 by the authors. Licensee MDPI, Basel, Switzerland. This article is an open access article distributed under the terms and conditions of the Creative Commons Attribution (CC BY) license (https:// creativecommons.org/licenses/by/ $4.0 /)$.
Abstract: Anti-diabetic compounds from natural sources are now being preferred to prevent or treat diabetes due to adverse effects of synthetic drugs. The decoction of Muntingia calabura leaves was traditionally consumed for diabetes treatment. However, there has not been any published data currently available on the processing effects on this plant's biological activity and phytochemical profile. Therefore, this study aims to evaluate the effect of three drying methods (freeze-drying (FD), air-drying (AD), and oven-drying (OD)) and ethanol:water ratios $(0,50$, and $100 \%)$ on in vitro anti-diabetic activities of M. calabura leaves. In addition, an ultrahigh-performance-liquid chromatography-electrospray ionization tandem mass spectrometry (UHPLC-ESI-MS/MS) method was used to characterize the metabolites in the active extract. The FD M. calabura leaves, extracted with $50 \%$ ethanol, is the most active extract that exhibits a high $\alpha$-glucosidase and $\alpha$-amylase inhibitory activities with $\mathrm{IC}_{50}$ values of $0.46 \pm 0.05$ and $26.39 \pm 3.93 \mu \mathrm{g} / \mathrm{mL}$, respectively. Sixty-one compounds were tentatively identified by using UHPLC-ESI-MS/MS from the most active extract. Quantitative analysis, by using UHPLC, revealed that geniposide, daidzein, quercitrin, 6-hydroxyflavanone, kaempferol, and formononetin were predominant compounds identified from the active extract. The results have laid down preliminary steps toward developing M. calabura leaves extract as a potential source of bioactive compounds for diabetic treatment.

Keywords: Muntingia calabura; $\alpha$-glucosidase inhibitor; $\alpha$-amylase inhibitor; LCMS identification; absolute quantification

\section{Introduction}

Diabetes mellitus (DM) is a chronic metabolic disorder and an inappropriate hyperglycemia due to either insulin secretion deficiency or a combination of insulin resistance and inadequate insulin secretion to compensate blood glucose levels [1]. While the type 1 is usually associated with the destruction of pancreatic islet $\beta$-cell by the autoimmune process, the type 2 diabetes involves a combination of insulin resistance and defective compensatory insulin secretion [2]. In Malaysia, one in five adults, or $18.3 \%$ of the population, is estimated to suffer from the implications of DM in 2019, and these numbers are expected to grow, as a spike has been observed from $13.4 \%$ diabetes prevalence in a 2015 report [3]. There are six major drug classes that manage hyperglycemia in DM patients, including biguanides (i.e., metformin), thiazolidinediones (i.e., pioglitazone), sulfonylureas (i.e., glimepiride), meglitinides (i.e., repaglinide), dipeptidyl peptidase IV inhibitors (i.e., sitagliptin), and $\alpha$-glucosidase inhibitors (i.e., acarbose) [1,4-7]. However, the naturally occurring anti-diabetic compounds are now gaining popularity as an efficient and wholesome approach toward diabetes management as an alternative compared to 
synthetic drugs that cause toxic side effects such as hepatic disorders and other negative gastrointestinal symptoms after the consumption over period of time $[8,9]$.

Muntingia calabura L. is one of those many traditional medicinal plants that is known to control blood glucose levels. It is extracted by steeping the dried leaves in hot water [10]. These leaves are also known to cure gastric ulcers, swelling of the prostate gland, and helps in alleviating headache and cold symptoms [11]. M. calabura, originating from the family of Muntingiaceae, commonly known as "ceri hutan" in Malaysia, is widely cultivated in the warmer areas of Asia, including Malaysia, Indonesia, Philippines, and tropical America. For its high adaptability to strive, even in poor soil conditions including acidic or alkaline, $M$. calabura is now the most commonly found roadside plants in Malaysia [12]. Several studies have demonstrated the positive attributes of $M$. calabura and its influence against gastric damages, bacterial and viral infections, hypoglycemic and analgesic effects $[10,12-14]$. M. calabura mainly consists of several compounds, such as triterpenoids (lupenone); flavonoids (5,7-dihydroxyflavanone, 7-hydroxyflavanone, 5-hydroxy-3,7,8-trimethoxyflavone, $5^{\prime}$-hydroxy-7,8,3', $4^{\prime}$-tetramethoxyflavan, 3,5-dihydroxy$7,4^{\prime}$-dimethoxyflavone); phytosterols ( $\beta$-sitostenone and $\beta$-sitosterol), and chalcones derivatives ( $2^{\prime}, 4^{\prime}$-dihydroxydihydrochalcone, $2^{\prime}, 4^{\prime}$-dihydroxychalcone, and isoliquiritigenin) [15-17]. Several studies have compiled the health benefits of these constituent compounds in ameliorating the diabetic complications [18-23].

Before commencement of an extraction process, the plant sample is required to undergo a pre-extraction treatment (drying and grinding) to increase the shelf-life, as well as to maximize the extraction of metabolites from the plant [24]. Drying method can be categorized into two types; thermal drying includes the application of heat on the plant sample (hot air-drying, oven-drying (OD), microwave-drying, and sun-drying), while non-thermal drying avoids direct heat to dry the sample (freeze-drying (FD) and air-drying (AD)) [25]. Herbal industries prefers to use oven and AD method in their commercial facilities, as these methods are cost effective and easy to accomplish [26]. The utilization of suitable solvent is one of the key aspects of extraction to give the highest metabolites recovery available in the plant sample. The use of high polarity solvents might affect the solubility of the non-polar compounds, likewise, upon the use of low polarity solvents [27]. The loss of metabolites that are not able to be extracted out may hinder the full capacity of a plant sample to be established as a good antihyperglycemic alternative regimen. Therefore, an efficient extraction process that distills and preserves the indispensable bioactive compounds, contributing to the hypoglycemic effect of a plant extract, is crucial.

Though the hypoglycemic bioactivity of this plant has been previously reported [14], the effects of the drying method and extracting solvent on M. calabura bioactive compounds and, hence, the hypoglycemic activity, has not been discovered. Therefore, this study aims to investigate the optimal combination of drying method and extracting solvents (ethanol:water) with appropriate ratio that can produce $M$. calabura extracts with the most desirable and potent in vitro anti-diabetic activities. In addition, an ultrahighperformance-liquid chromatography-electrospray ionization tandem mass spectrometry (UHPLC-ESI-MS/MS) method was used to characterize the metabolites of the active extract, based on their MS/MS data, for the first time. The results obtained from this study will allow recommendations on the best combination of drying method and extracting solvent to obtain M. calabura extract with significant potential in selected bioactivity and high productivity.

\section{Results and Discussion}

\subsection{Influence of Varied Drying Process and Ethanol Concentrations on Anti-Diabetic Activity}

The bioactivity results of $M$. calabura leaves extracts, from different drying methods and ethanol:water ratios, are shown in Table 1. M. calabura leaves extracts were tested in two in vitro anti-diabetic assays, named $\alpha$-glucosidase and $\alpha$-amylase inhibition activity. In these two activities, the hypoglycemic potential of M. calabura extracts, to reduce the blood sugar level through competitive binding to the active site of the enzyme to prevent the 
conversion of carbohydrates to simple glucose, were determined [28]. The $\alpha$-glucosidase inhibitory activity was designed to assess the ability of an extract to suppress the active enzyme from catalyzing the conversion of glucose from the disaccharides, which occurs in the small intestine [29]. In this study, PNPG, a specific substrate that allows hydrolyzation to 4-nitrophenol (yellow colored product) by $\alpha$-glucosidase enzyme, quantitates at a maximum wavelength of $405 \mathrm{~nm}$ [30], while $\alpha$-amylase inhibitory activity was used to measure the free carbonyl group of the reducing sugar (maltose) converted by the $\alpha$-amylase from the complex carbohydrates (potato starch) [31]. The aldehyde group from the maltose reduces the yellow colored DNS to form 3-amino-5-nitrosalicylic acid (brick red colored solution) [31]. The concentration of maltose presence in the sample, determine the intensity of the color at a wavelength of $540 \mathrm{~nm}$ [32].

Table 1. $\alpha$-Glucosidase and $\alpha$-amylase inhibitory activity of $M$. calabura leaves dried with oven-drying (OD), air-drying (AD), and freeze-drying (FD) and extracted with 0, 50, and 100\% ethanol.

\begin{tabular}{|c|c|c|c|}
\hline Drying Method & $\begin{array}{c}\text { Ethanol:Water } \\
\text { Ratio }\end{array}$ & $\begin{array}{c}\alpha \text {-Glucosidase Inhibitory } \\
\text { Assay } \mathrm{IC}_{50}(\mu \mathrm{g} / \mathrm{mL})\end{array}$ & $\begin{array}{l}\alpha \text {-Amylase Inhibitory Assay } \\
\operatorname{IC}_{50}(\mu \mathrm{g} / \mathrm{mL})\end{array}$ \\
\hline \multirow{3}{*}{ OD } & 100 & $1.13 \pm 0.13^{\mathrm{Ba}}$ & $59.39 \pm 2.47 \mathrm{Ba}$ \\
\hline & 50 & $0.81 \pm 0.09 \mathrm{Ca}$ & $45.77 \pm 2.46^{\mathrm{Ca}}$ \\
\hline & 0 & $2.76 \pm 0.09 \mathrm{Aa}$ & $105.95 \pm 1.57^{\mathrm{Ac}}$ \\
\hline \multirow{3}{*}{$\mathrm{AD}$} & 100 & $1.07 \pm 0.06^{\mathrm{Ba}}$ & $53.34 \pm 1.64^{\mathrm{Bb}}$ \\
\hline & 50 & $0.59 \pm 0.14^{\mathrm{Bb}}$ & $35.32 \pm 2.35^{\mathrm{Cb}}$ \\
\hline & 0 & $2.41 \pm 1.00 \mathrm{Aa}$ & $114.43 \pm 2.22^{\mathrm{Ab}}$ \\
\hline \multirow{3}{*}{ FD } & 100 & $0.65 \pm 0.04^{\mathrm{Bb}}$ & $23.84 \pm 1.85^{\mathrm{Bc}}$ \\
\hline & 50 & $0.46 \pm 0.05^{\mathrm{Bb}}$ & $26.39 \pm 3.93^{\mathrm{Bc}}$ \\
\hline & 0 & $2.01 \pm 0.86^{\mathrm{Aa}}$ & $185.17 \pm 2.11^{\mathrm{Aa}}$ \\
\hline \multirow[t]{2}{*}{ Standard } & Quercetin & $2.15 \pm 0.26$ & - \\
\hline & Acarbose & - & $0.68 \pm 0.14$ \\
\hline
\end{tabular}

The $\mathrm{IC}_{50}$ values of five biological replicates are expressed as means \pm standard deviation. The uppercase letter is used to demonstrate the different ethanol:water ratio for the same drying process, while the lowercase letter is used to demonstrate the varied drying process for the same ethanol:water ratio. The different superscript letters represent significant differences at $p<0.05$ between samples.

The results demonstrated in Table 1 show the $\mathrm{IC}_{50}$ value of the $\alpha$-glucosidase inhibition activity of $M$. calabura leaves extracts, ranging from $0.46-2.76 \mu \mathrm{g} / \mathrm{mL}$ in comparison to quercetin $(2.15 \pm 0.26 \mu \mathrm{g} / \mathrm{mL})$, while for $\alpha$-amylase inhibition activity, the $\mathrm{IC}_{50}$ value, ranging from $23.84-185.17 \mu \mathrm{g} / \mathrm{mL}$ in comparison to acarbose $(0.68 \pm 0.14 \mu \mathrm{g} / \mathrm{mL})$. In $\alpha$-glucosidase inhibition activity, the effect of different ethanol:water ratios played the most significant role that affected $\alpha$-glucosidase inhibition ability of $M$. calabura leaves compared to the different drying methods. The 50 and $100 \%$ ethanolic extracts from FD and AD leaves showed the lowest $\mathrm{IC}_{50}$ value with no significant difference $(p>0.05)$, ranging from $0.46 \pm 0.05$ to $1.07 \pm 0.06 \mu \mathrm{g} / \mathrm{mL}$. On the contrary, the $\mathrm{IC}_{50}$ value of $50 \%$ ethanolic extract from OD leaves was the lowest compared to that of the 100 and $0 \%$ ratios from the same drying method, whereas the $0 \%$ ethanolic extract from all the drying methods showed significantly lower $\alpha$-glucosidase inhibition potential compared to that of other extracts. As for the $\alpha$-amylase inhibition activity, the lowest $\mathrm{IC}_{50}$ value was found in the $50 \%$ ethanolic extract, regardless of its drying method, and in the $100 \%$ ethanolic extract from the FD method. When comparing the different drying methods, the FD M. calabura leaves showed the highest $\alpha$-amylase inhibition capability compared to the $\mathrm{AD}$ and OD methods in both 50 and 100\% ethanolic extracts. However, the OD leaves showed the lowest $\mathrm{IC}_{50}$ value when extracted with $0 \%$ ethanol. The use of $50 \%$ ethanol, evidently, was the best ethanol:water ratio to extract out the phytochemical constituents with hypoglycemic potential in $M$. calabura leaves for both tested bioactivities. In line with the previous in vitro study, where the use of alcohol and water mixture could efficiently extract out the wider spectrum of phytochemicals constituents that might contribute to the bioactivity as compared to a mono-component solvent system [33]. Besides that, the utilization of the $50 \%$ ethanolic ratio allows utilization of less organic solvent, increasing 
extract's solubility in less toxic organic environment and confirming its usage harmlessly in in vivo studies [34].

In this study, FD and AD extracts were procured as the most effective drying methods in order to identify the $\alpha$-glucosidase and $\alpha$-amylase inhibitors followed by OD extraction. The absence of thermal degradation hindered the degradative enzyme to function [35]. Several studies have concurred that the FD method enables higher retention of phytochemical compounds that leads to enhanced biological activity of the plant [36]. In contrast, the thermal processing such as oven-drying, hot air-drying, and microwave-drying impeded the extraction of phytochemicals of the plant by thermal breakdown, disrupting the integrity of cell structure and migration of components, catalyzing further disruption by various chemical reactions such as enzymes, light, and oxygen [37]. In addition, the utilization of the FD method will shorten the extraction process by expediting the drying time, compared to the $\mathrm{AD}$ technique, as well as potentially providing higher yield of anti-diabetic phytochemical constituents [38,39]. Hence, the $50 \%$ ethanol:water ratio on FD M. calabura leaves, with strong $\alpha$-glucosidase and $\alpha$-amylase inhibitory activity, can be potentially exploited further to create a natural regimen from M. calabura leaves to aid in the blood sugar management of a diabetic patient.

\subsection{UHPLC-ESI-MS/MS Characterization of Phytoconstituents in the M. calabura Leaves Extract}

Based on the anti-diabetic activity of $M$. calabura leaves, the FD 50\% ethanolic extract was identified and selected as the most active extract. This extract was then subjected to UHPLC-ESI-MS/MS identification to have better insight on the constituents present that might enhance the bioactivities. Figure 1 shows the total ion chromatogram and UV-Vis chromatogram $(254 \mathrm{~nm}$ ) of the FD 50\% ethanolic $M$. calabura leaves extract for both positive and negative ion mode. A total of 61 compounds (Table 2) were putatively identified based on their molecular ions in the full scan mass spectra, retention time, fragmentation patterns, mass error, and UV absorption spectra supported with database mining, such as MassBank databases (https:/ / massbank.eu/MassBank/), Human Metabolomics Databases (HMDB) (https://hmdb.ca/), Metabolomics Workbench databases (https://www.metabolomicsworkbench.org/), Chemspider databases (http: //www.chemspider.com/), and MassFrontier (version 8.0) software (Thermo Scientific, Waltham, MA, USA). The compounds identified include five catechin derivatives, five types of kaempferol derivatives, three types of quercetin derivatives, one apigenin derivative compound, three types of luteolin derivatives, seven types of daidzein derivatives, 19 types of other flavonoids, two types of anthocyanin compounds, two types of chalcone compounds, six types of quinone derivatives, two types of lactones derivatives, two types of alkaloid derivatives, two types of sugar, one terpene glycoside, and one ellagitannins derivative.

\subsubsection{Catechin Derivatives}

Catechin (Peak 48) was identified at $t_{\mathrm{R}}=1.68 \mathrm{~min}$ with protonated molecule $[\mathrm{M}+\mathrm{H}]^{+}$ at $m / z$ 291.0640. The fragmentation pattern in the MS/MS analysis for this compound were at $m / z 244.9747[\mathrm{M}+\mathrm{H}-46]^{+}\left(\right.$loss of $\left.\mathrm{C}_{2} \mathrm{H}_{6} \mathrm{O}\right), 207.0665[\mathrm{M}+\mathrm{H}-84]^{+}\left(\right.$loss of $\left.\mathrm{C}_{4} \mathrm{H}_{4} \mathrm{O}_{2}\right)$, and 139.0396 [M+H-152] $]^{+}$(loss of $\mathrm{C}_{8} \mathrm{H}_{8} \mathrm{O}_{3}$ ) [40]. Epigallocatechin (Peak 3) and gallocatechin (Peak 6) were identified at $t_{R}=1.24$ and $1.40 \mathrm{~min}$, respectively, with a deprotonated molecule $[\mathrm{M}-\mathrm{H}]^{-}$at $m / z$ 305.0668. The ions later produced three fragmentation ions in the MS/MS analysis at $m / z 289.0233$ as the base peak of catechin, 245.0284 [M-H-60] ${ }^{-}$due to loss of $\mathrm{C}_{2} \mathrm{H}_{4} \mathrm{O}_{2}, 219.0655$ [M-H-86] ${ }^{-}$due to loss of $\mathrm{C}_{3} \mathrm{H}_{2} \mathrm{O}_{3}$ and 167.0338 [M-H-138] $]^{-}$due to the loss of $\mathrm{C}_{7} \mathrm{H}_{6} \mathrm{O}_{3}$ [40]. Figure 2 demonstrates the common fragmentation pathways of the catechin derivatives. Another catechin derivatives named epigallocatechin gallate (Peak 51) was identified at $t_{\mathrm{R}}=9.68$ min with protonated molecule $[\mathrm{M}+\mathrm{H}]^{+}$at $m / z 459.0942$, with three fragmentation ions in the MS/MS analysis at $m / z 321.0591[\mathrm{M}+\mathrm{H}-138]^{+}$due to dissociation of $\mathrm{C}_{7} \mathrm{H}_{6} \mathrm{O}_{3}, 289.0771[\mathrm{M}+\mathrm{H}-170]^{+}$as the base peak of catechin, and $275.0818[\mathrm{M}+\mathrm{H}-184]^{+}$ due to loss of $\mathrm{C}_{8} \mathrm{H}_{8} \mathrm{O}_{5}$ [40]. 

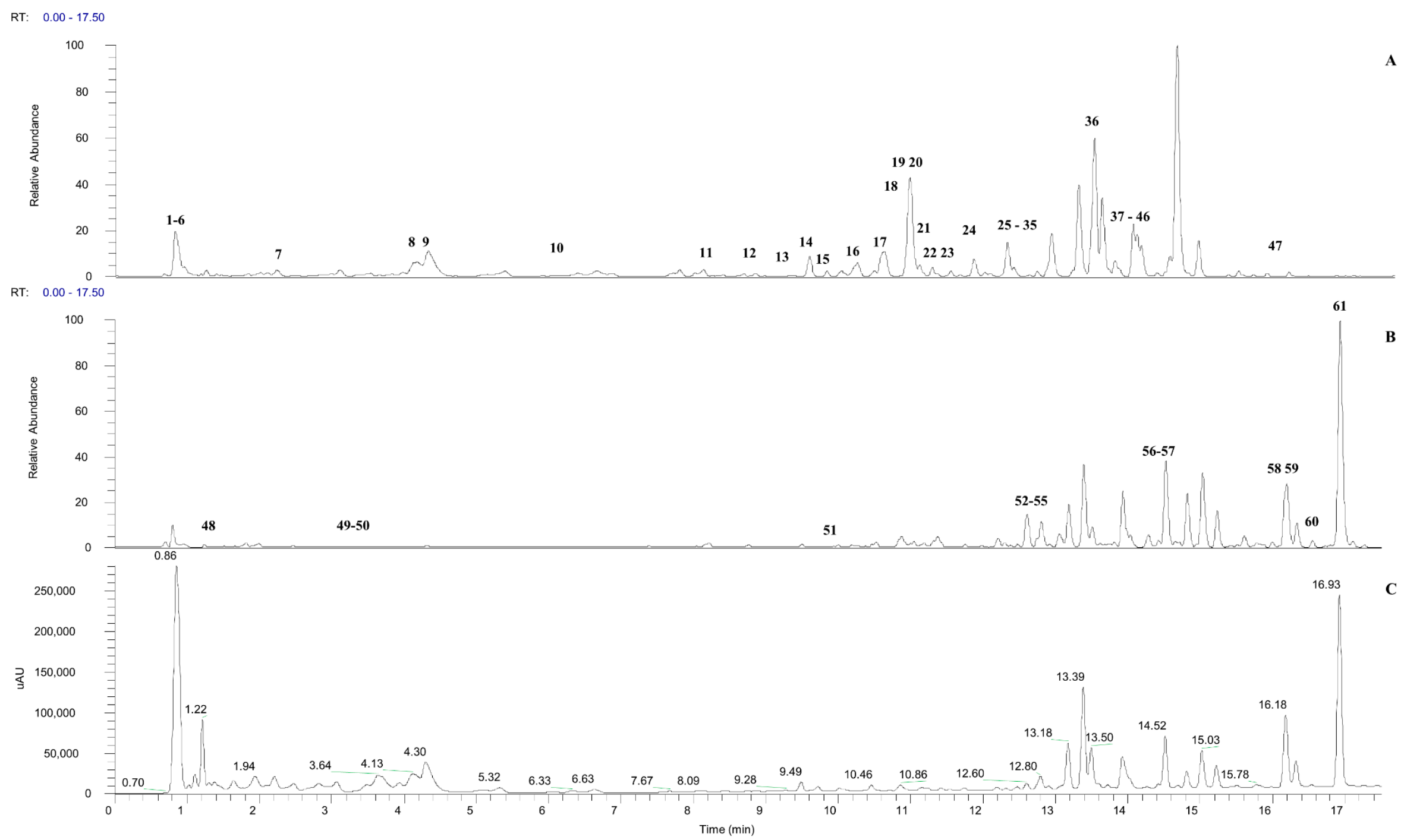

Figure 1. Total ion chromatogram (TIC) and UV-Vis chromatogram $(254 \mathrm{~nm})($ C) of M. calabura FD leaves extracted with $50 \%$ ethanol in negative (A) and positive ion mode $(\mathbf{B})$, respectively. 


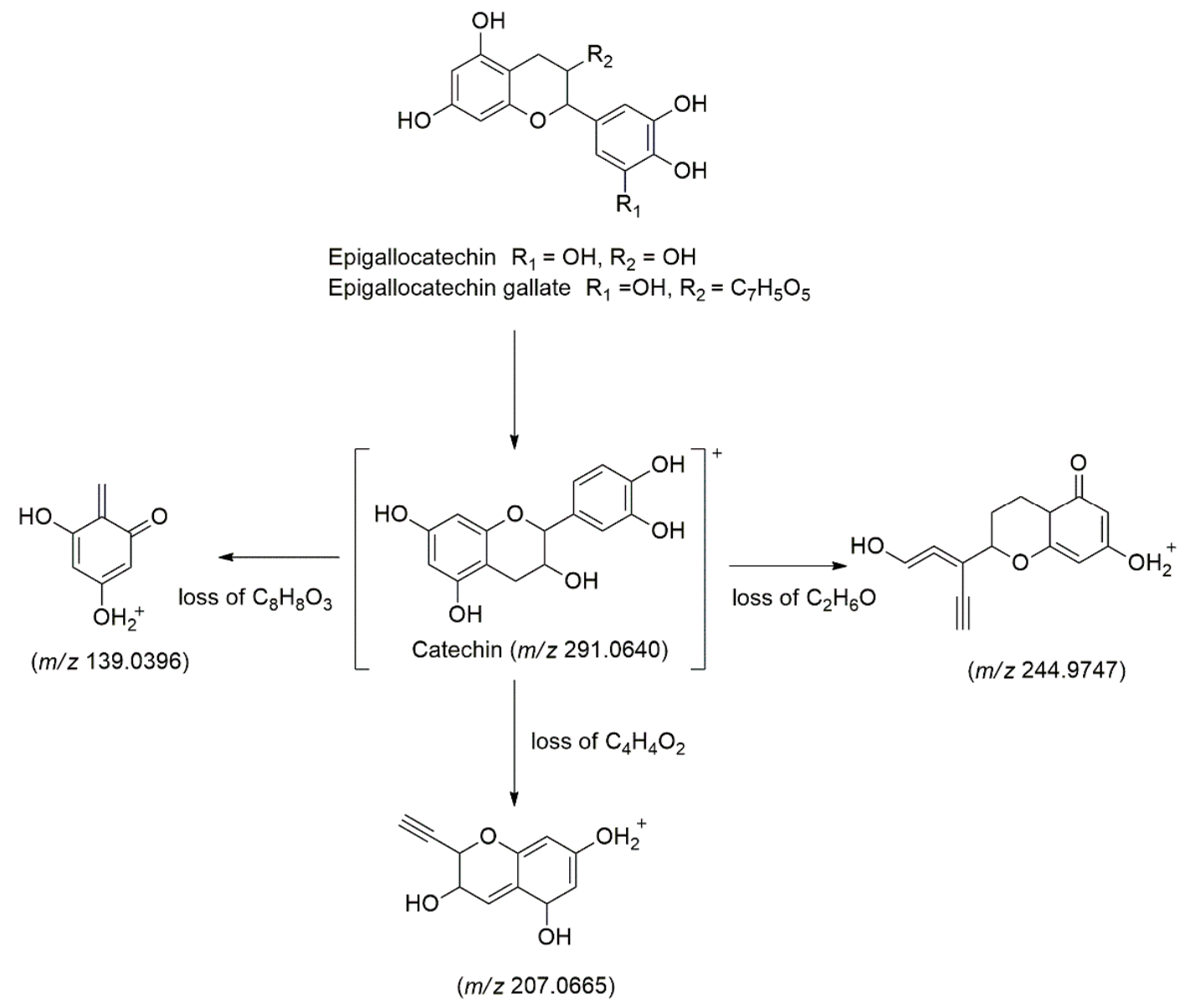

Figure 2. The main fragmentation pathways of the catechin derivatives.

\subsubsection{Kaempferol Derivatives}

Kaempferol (Peak 24) was identified at $t_{R}=11.87$ min with a deprotonated molecule $[\mathrm{M}-\mathrm{H}]^{-}$at $\mathrm{m} / \mathrm{z} 285.0401$, which later produced three characteristic fragment ions in the MS/MS analysis at $m / z 269.0448$ [M-H-16] ${ }^{-}$due to the loss of $\mathrm{CH}_{4}, m / z 216.9897$ [M-H-68] due to the loss of $\mathrm{C}_{4} \mathrm{H}_{4} \mathrm{O}$ and $m / z 119.0491$ [M-H-166] ${ }^{-}$due to the loss of $\mathrm{C}_{8} \mathrm{H}_{6} \mathrm{O}_{4}$ [40]. Identification of kaempferol was confirmed with the authentic standard. Buddlenoid A (Peak 12) and its isomer (Peak 14) were identified at $\left(t_{R}=9.43\right.$ and $9.75 \mathrm{~min}$ ). These compounds showed a deprotonated molecule $[\mathrm{M}-\mathrm{H}]^{-}$at $m / z$ 593.1304, which later produced six characteristic fragment ions in the MS/MS analysis at $m / z 447.0935$ [M-H-146] $^{-}$, 429.0823 [M-H-164] $]^{-}$, and 285.0404 [M-H-308] ${ }^{-}$. The fragmentations occur due to the loss of $\mathrm{C}_{9} \mathrm{H}_{6} \mathrm{O}_{2}, \mathrm{C}_{9} \mathrm{H}_{8} \mathrm{O}_{3}$, and $\mathrm{C}_{15} \mathrm{H}_{16} \mathrm{O}_{7}$, respectively. Besides that, the compounds also show a fragmentation pattern typical of kaempferol aglycone at $m / z 269.0448,216.9897$, and 119.0491 [41]. This compound was previously isolated and characterized in this plant by Nshimo et al. [42]. Figure 3 depicts the main fragmentation pathways of the kaempferol derivatives. Buddlenoid A dimer (Peak 13) was also identified in abundance at $t_{\mathrm{R}}=9.49 \mathrm{~min}$ with a deprotonated molecule $[\mathrm{M}-\mathrm{H}]^{-}$at $m / z 1187.2678$. This compound exhibited the same fragmentation patterns in the MS/MS analysis as buddlenoid A, with double of its monomer [41]. Another kaempferol derivative was also identified in the chromatogram at $t_{\mathrm{R}}=13.63 \mathrm{~min}$, with a deprotonated molecule $[\mathrm{M}-\mathrm{H}]^{-}$at $\mathrm{m} / \mathrm{z} 287.0539$. Additionally, $m / z 271.0607$ [M-H-16] ${ }^{-}$occurs due to loss of $\mathrm{CH}_{4}$ in the MS/MS analysis, while $m / z 269.0723,216.9894$, and 119.0077 are typical fragments for kaempferol derivatives [40]. Hence, this compound was identified as dihydrokaempferol (Peak 37). 


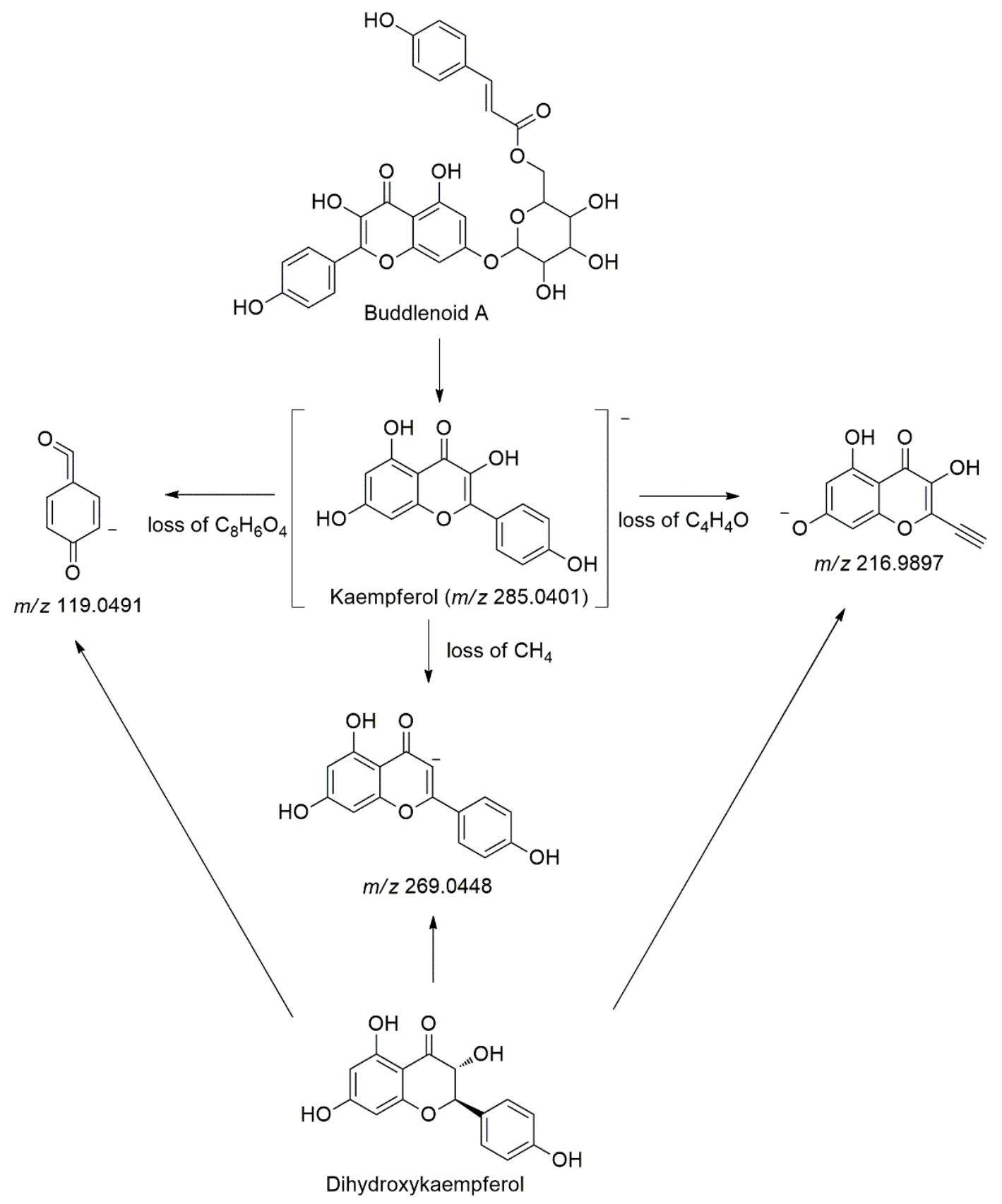

Figure 3. The main fragmentation pathways of the kaempferol derivatives.

\subsubsection{Quercetin Derivatives}

Quercitrin (Peak 21) and its isomer (Peak 23) was identified at $t_{R}=11.02$ and $11.17 \mathrm{~min}$, with a deprotonated molecule $[\mathrm{M}-\mathrm{H}]^{-}$at $m / z$ 447.2237, which later produced three characteristic fragment ions in the MS/MS analysis at $m / z 301.1495[\mathrm{M}-\mathrm{H}-146]^{-}$as the base peak for quercetin, $m / z 285.2063$ [M-H-162] ${ }^{-}$due to the loss of $\mathrm{C}_{6} \mathrm{H}_{10} \mathrm{O}_{5}$ and $m / z 245.0717$ [M-H-202] ${ }^{-}$ due to the loss of $\mathrm{C}_{8} \mathrm{H}_{10} \mathrm{O}_{6}$ [40]. Identification of this compound was further confirmed with the authentic standard. Rhamnetin (Peak 52) were also characterized at $t_{R}=12.58 \mathrm{~min}$ based on its protonated molecule $[\mathrm{M}+\mathrm{H}]^{+}$at $\mathrm{m} / z 317.0671$ and the three fragmentation ions in the MS/MS analysis. At $m / z 301.0973[\mathrm{M}+\mathrm{H}-16]^{+}$arose as the base peak for quercetin, as shown in Figure 4. The $m / z 285.0734[\mathrm{M}+\mathrm{H}-31]^{+}$and $m / z 245.1063$ [M+H-71] $]^{+}$occurred due to the loss of $\mathrm{CH}_{3} \mathrm{O}$ and $\mathrm{C}_{3} \mathrm{H}_{3} \mathrm{O}_{2}$, respectively [40]. 
<smiles></smiles>

Quercitrin $\mathrm{R}_{1}=$ Rhamnose, $\mathrm{R}_{2}=\mathrm{OH}$ Rhamnetin $\mathrm{R}_{1}=\mathrm{OH}, \mathrm{R}_{2}=\mathrm{OCH}_{3}$<smiles>O=c1c(O)c(-c2ccc(O)c(O)c2)oc2cc(O)cc(O)c12</smiles>

Quercetin $(\mathrm{m} / \mathrm{z} 301.0973)$

Figure 4. The main fragmentation pathways of the quercetin derivatives.

\subsubsection{Apigenin Derivatives}

One apigenin derivatives named vitexin hydroxymethylglutarate (Peak 30) was identified at $\mathrm{t}_{\mathrm{R}}=12.72 \mathrm{~min}$, based on its deprotonated molecule $[\mathrm{M}-\mathrm{H}]^{-}$at $\mathrm{m} / \mathrm{z} 571.748$ and the three fragmentation ions in the MS/MS analysis. The product ions were $m / z 513.0697$ [M-H-62] ${ }^{-}$ due to $\mathrm{CH}_{2} \mathrm{O}_{3}, \mathrm{~m} / \mathrm{z} 341.1581$ [M-H-234] $]^{-}$occur due to loss of $\mathrm{C}_{9} \mathrm{H}_{14} \mathrm{O}_{7}$ and $\mathrm{m} / \mathrm{z} 269.1393$ [M-H-306] ${ }^{-}$ as the base peak of apigenin, as shown in Figure 5 [43].<smiles>CC(O)(CC(=O)O)CC(=O)OCC1OC2OC1C(O)C(O)C2c1c(O)cc(O)c2c(=O)cc(-c3ccc(O)cc3)oc12</smiles><smiles>O=c1cc(-c2ccc(O)cc2)oc2cc(O)cc(O)c12</smiles>

Apigenin $(m / z 269.1393)$

Vitexin hydroxymethylglutarate

Figure 5. The fragmentation pathways of the apigenin derivatives.

\subsubsection{Luteolin Derivatives}

One luteolin derivative named velutin (Peak 40) was tentatively identified, as they share three significant product ions $[\mathrm{M}-\mathrm{H}]^{-}$at $\mathrm{m} / \mathrm{z} 285.0284,255.0299,227.0350$, and 213.0395, which were the base peaks for luteolin aglycone [40]. Velutin and its isomers (Peak 40, 45, and 46) were identified based on its deprotonated molecule $[\mathrm{M}-\mathrm{H}]^{-}$at $\mathrm{m} / \mathrm{z} 313.0719$ at $\mathrm{t}_{\mathrm{R}}=14.03,15.01$, and $15.19 \mathrm{~min}$ [40]. Figure 6 shows the main fragmentation pathways found in luteolin derivatives.

\subsubsection{Daidzein Derivatives}

Daidzein (Peak 54) and its isomer (Peak 55) were identified with a protonated molecule $[\mathrm{M}+\mathrm{H}]^{+}$at $m / z 255.0661$ at $t_{\mathrm{R}}=13.13$ and $13.29 \mathrm{~min}$, respectively. This compound was further characterized with the three fragmentation ions in MS/MS MS/MS analysis at $\mathrm{m} / \mathrm{z} 227.0694[\mathrm{M}+\mathrm{H}-28]^{+}$with the loss of $\mathrm{C}_{2} \mathrm{H}_{4}, \mathrm{~m} / z 213.0553[\mathrm{M}+\mathrm{H}-42]^{+}$, with loss of $\mathrm{C}_{2} \mathrm{H}_{2} \mathrm{O}$ and $m / z 200.9240[\mathrm{M}+\mathrm{H}-54]^{+}$, and with the loss of $\mathrm{C}_{3} \mathrm{H}_{2} \mathrm{O}$ [40]. Identification of daidzein was confirmed with the authentic standard. Three of daidzein derivatives were also identified in the sample named ononin (Peak 53), 3'-hydroxydaidzein (Peak 56), and formononetin (Peak 58). Ononin (Peak 53) was identified at $t_{R}=13.00 \mathrm{~min}$ based on its protonated molecule $[\mathrm{M}+\mathrm{H}]^{+}$at $\mathrm{m} / z 431.1330$ and the fragmentation ions at MS/MS analysis that are similar to the base peak of daidzein, as shown in Figure 7 [40]. Additionally, 3'-hydroxydaidzein (Peak 56) and its isomer (Peak 57) with protonated molecule $[\mathrm{M}+\mathrm{H}]^{+}$at $\mathrm{m} / \mathrm{z} 271.0611$ were tentatively identified based on their similar base peak, as of daidzein, as demonstrated in Figure 7 at $t_{R}=14.38$ and 14.78 min, respectively [44]. Then, $3^{\prime}$-hydroxydaidzein was previously isolated and characterized in this plant by Matsuda et al. [45]. While at $t_{R}=16.13$ and 16.29, formononetin (Peak 58) and its isomer 
(Peak 59) were identified based on its protonated molecule $[\mathrm{M}+\mathrm{H}]^{+}$at $\mathrm{m} / \mathrm{z} 269.0819$ and the four fragmentation ions at MS/MS analysis that agreed to the base peak of daidzein [40]. The identification of this compound was confirmed with the authentic standard.

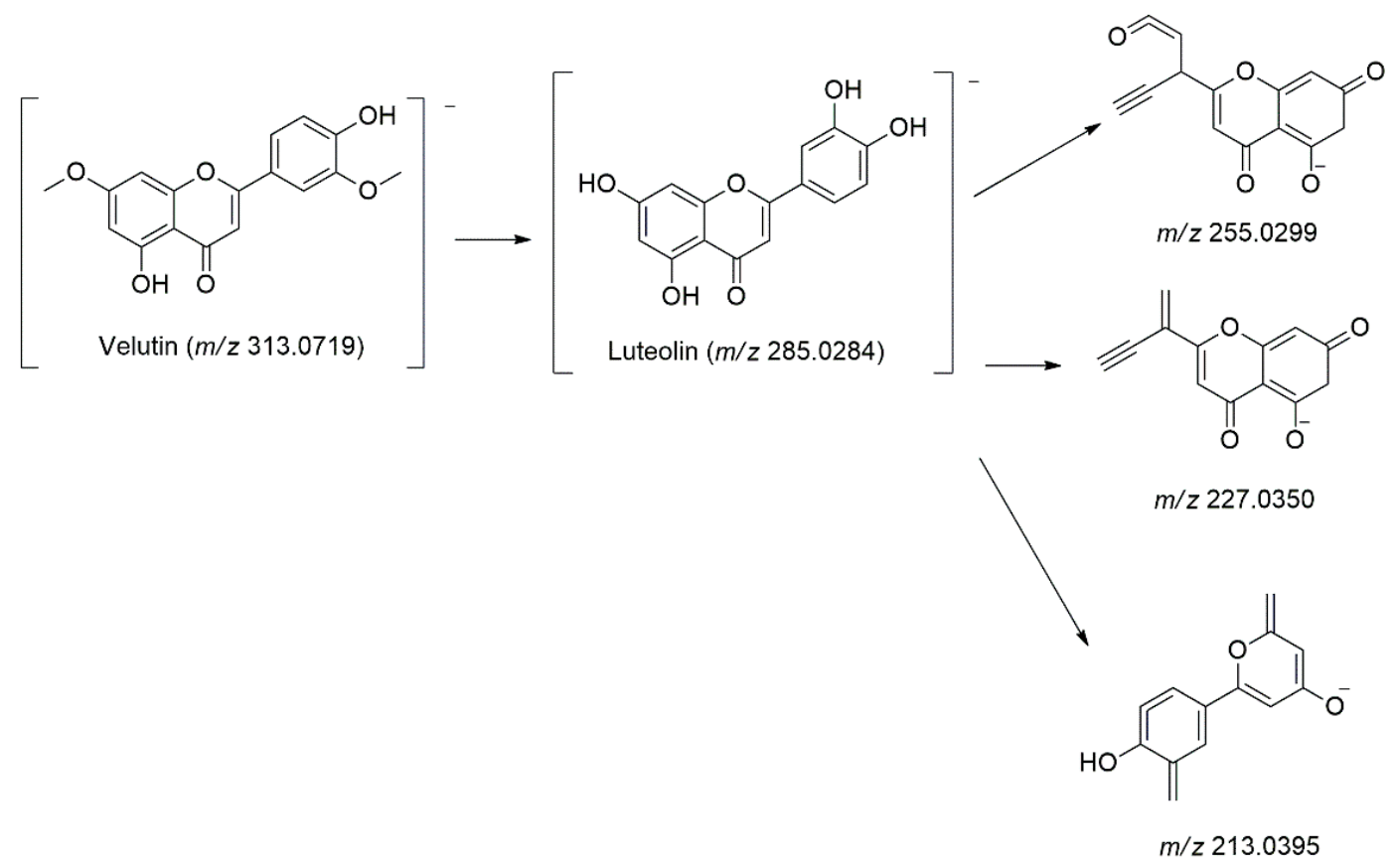

Figure 6. The fragmentation pathways of the luteolin derivatives.

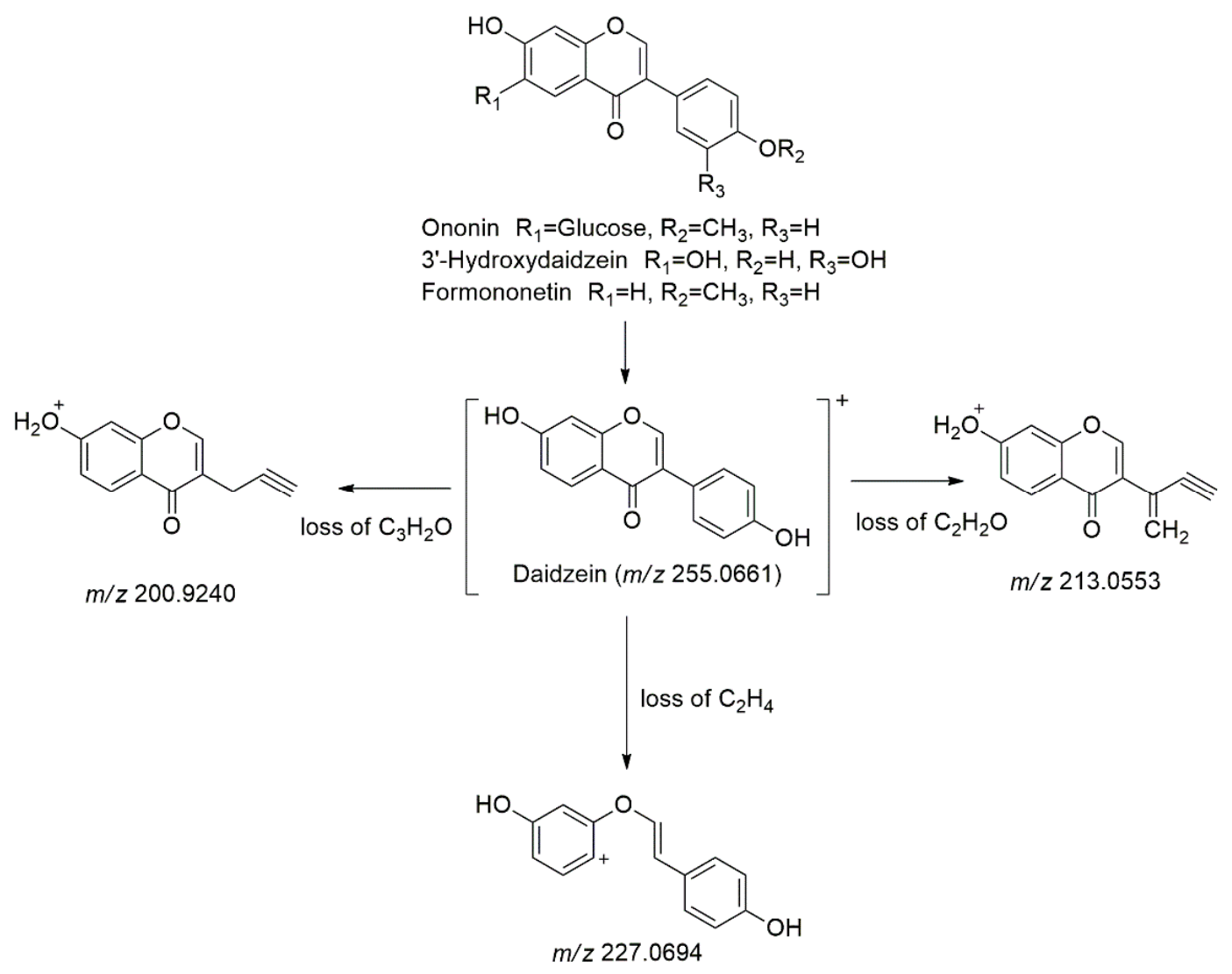

Figure 7. The fragmentation pathways of the daidzein derivatives. 


\subsubsection{Other Flavonoids}

Additionally, $3^{\prime}$-Hydroxy-7,8, $4^{\prime}, 5^{\prime}$-tetramethoxyflavone (Peak 4) was identified at $t_{\mathrm{R}}=1.36 \mathrm{~min}$ with a deprotonated molecule $[\mathrm{M}-\mathrm{H}]^{-}$at $\mathrm{m} / \mathrm{z} 357.1195$, which later produced three fragmentation ions at MS/MS analysis at $\mathrm{m} / \mathrm{z} 270.8385$ [M-H-86] ${ }^{-}$due to the cleavage of $\mathrm{C}_{4} \mathrm{H}_{6} \mathrm{O}_{2}, \mathrm{~m} / \mathrm{z} 224.8610$ [M-H-132] ${ }^{-}$due to the cleavage of $\mathrm{C}_{6} \mathrm{H}_{12} \mathrm{O}_{3}$, and $m / z 179.0586$ [M-H-178] $]^{-}$due to cleavage of $\mathrm{C}_{10} \mathrm{H}_{10} \mathrm{O}_{3}$ [46]. This compound was previously isolated and characterized in this plant by Kaneda et al. [46].

Peak 7 was identified as $7,8,3^{\prime}, 4^{\prime}, 5^{\prime}$-pentamethoxyflavone at $t_{R}=2.42$ min with a deprotonated molecule $[\mathrm{M}-\mathrm{H}]^{-}$at $m / z$ 371.0986. This ion was then further fragmented in MS/MS analysis and produced three fragmentation ions at $m / z 296.98684$ [M-H-74] $]^{-}$with the loss of $\mathrm{C}_{3} \mathrm{H}_{6} \mathrm{O}_{2}, \mathrm{~m} / z 240.8795$ [M-H-130] ${ }^{-}$with the loss of $\mathrm{C}_{6} \mathrm{H}_{10} \mathrm{O}_{3}$, and $\mathrm{m} / z 231.0506$ [M-H-140] ${ }^{-}$ with the loss of $\mathrm{C}_{7} \mathrm{H}_{8} \mathrm{O}_{3}$ [46]. Previously, 7,8,3',4',5'-pentamethoxyflavone was also isolated and characterized in M. calabura by Kaneda et al. [46].

At $t_{R}=8.70 \mathrm{~min}$, another flavonoid named hiravanone (Peak 11) was identified based on its deprotonated molecule $[\mathrm{M}-\mathrm{H}]^{-}$at $m / z 437.0466$, with three fragmentation ions in MS/MS analysis at $m / z 296.8747$ [M-H-140] ${ }^{-}, 288.7813$ [M-H-148] ${ }^{-}$, and 242.8798 [M-H-194] ${ }^{-}$ due to the loss of $\mathrm{C}_{7} \mathrm{H}_{8} \mathrm{O}_{3}, \mathrm{C}_{9} \mathrm{H}_{8} \mathrm{O}_{2}$, and $\mathrm{C}_{10} \mathrm{H}_{10} \mathrm{O}_{4}$, respectively [47]. This compound was previously isolated and characterized in this plant by Seo et al. [47].

Then, 3,5,8-Trihydroxy-7-methoxyflavanone (Peak 16) and its isomers (Peak 17 and 18) were identified based on its deprotonated molecule $[\mathrm{M}-\mathrm{H}]^{-}$at $\mathrm{m} / z 301.0721$ at $\mathrm{t}_{\mathrm{R}}=10.47$, 10.63 , and $10.78 \mathrm{~min}$, respectively, with three fragmentation ions in the MS/MS analysis at $m / z 286.0490$ [M-H-14] ${ }^{-}$due to the loss of $\mathrm{CH}_{2}, \mathrm{~m} / \mathrm{z} 269.0465$, due to the loss of $\mathrm{CH}_{4} \mathrm{O}$, and $\mathrm{m} / z 211.0475$ [M-H-90] ${ }^{-}$due to the loss of $\mathrm{C}_{7} \mathrm{H}_{6}$ [16]. Previously, 3,5,8Trihydroxy-7-methoxyflavanone was isolated and characterized in the leaves of $M$. calabura by Su et al. [16].

A deprotonated molecule $[\mathrm{M}-\mathrm{H}]^{-}$at $m / z 237.0555$ and its two fragmentation ions in MS/MS analysis at $m / z 209$ [M-H-28] ${ }^{-}$occur due to loss of CO, and $m / z 160$ [M-H-77] ${ }^{-}$ occurs due to the loss of $\mathrm{C}_{6} \mathrm{H}_{5}$, which was identified as hydroxyflavone (Peak 22) at $t_{R}=11.13 \min [40]$.

At $t_{R}=12.30 \mathrm{~min}, 6,8$-diprenyleriodictyol (Peak 25) was tentatively identified with the deprotonated molecule $[\mathrm{M}-\mathrm{H}]^{-}$at $\mathrm{m} / \mathrm{z}$ 423.0928. Three fragmentation ions occur in MS/MS analysis due to loss of $\mathrm{C}_{4} \mathrm{H}_{6} \mathrm{O}, \mathrm{C}_{8} \mathrm{H}_{7} \mathrm{O}_{2}$, and $\mathrm{C}_{11} \mathrm{H}_{8} \mathrm{O}_{2}$ at $\mathrm{m} / \mathrm{z} 353.2442$ [M-H-70] ${ }^{-}, 287.6386$ [M-H-135] $]^{-}$, and 251.0923 [M-H-172] ${ }^{-}$, respectively [40]. This compound was previously isolated and characterized in this plant by Seo et al. [47].

Cirsiliol (Peak 27) and its isomer (Peak 28) were putatively identified at $t_{R}=12.50$ and $12.66 \mathrm{~min}$, based on its deprotonated molecule $[\mathrm{M}-\mathrm{H}]^{-}$at $\mathrm{m} / \mathrm{z} 329.0672$ and its fragmentation ions in MS/MS analysis at $\mathrm{m} / \mathrm{z} 314.0419$ [M-H-15] ${ }^{-}$, due to the loss of $\mathrm{CH}_{3}, \mathrm{~m} / \mathrm{z}$ 299.0198 [M-H-30] $^{-}$due to the loss of $\mathrm{CH}_{2} \mathrm{O}$ and $\mathrm{m} / \mathrm{z} 285.0399$ [M-H-44] ${ }^{-}$due to the loss of $\mathrm{C}_{2} \mathrm{H}_{4} \mathrm{O}$ [40].

At deprotonated molecule $[\mathrm{M}-\mathrm{H}]^{-} \mathrm{m} / z 343.0823$ with $\mathrm{t}_{\mathrm{R}}=12.96 \mathrm{~min}$, a compound named 8,3'-dihydroxy-7, $4^{\prime}, 5^{\prime}$-trimethoxyflavone (Peak 32) was identified with three characteristic fragmentation ions in MS/MS analysis at $m / z 327.0524$ [M-H-16 $]^{-}, 313.0357$ [M-H-30] $]^{-}$, and 256.9828 [M-H-86 $]^{-}$. These ions produced, due to the loss of $\mathrm{CH}_{4}, \mathrm{CH}_{2} \mathrm{O}$ and $\mathrm{C}_{4} \mathrm{H}_{6} \mathrm{O}_{2}$, respectively [46]. Previously, 8,3'-dihydroxy-7,4',5'-trimethoxyflavone was isolated and characterized in this plant species by Kaneda et al. [46].

Dimethoxyhydroxyflavanone (Peak 33) and its isomer (Peak 36) were identified based on its deprotonated molecule $[\mathrm{M}-\mathrm{H}]^{-}$at $\mathrm{m} / \mathrm{z} 299.0196$ at $\mathrm{t}_{\mathrm{R}}=13.31$ and $13.47 \mathrm{~min}$. This ion later produced four fragmentation ions in MS/MS analysis at $m / z 284.0326$ [M-H-15] $]^{-}$due to the loss of $\mathrm{CH}_{3}, m / z 269.0457$ [M-H-30] ${ }^{-}$due to the loss of $\mathrm{CH}_{2} \mathrm{O}, \mathrm{m} / z$ 255.0300 [M-H-44] ${ }^{-}$ due to the loss of $\mathrm{CO}_{2}$, and $\mathrm{m} / z 239.0348$ [M-H-60] $]^{-}$due to the loss of $\mathrm{C}_{3} \mathrm{H}_{8} \mathrm{O}$ [40].

Kievitone (Peak 38) was identified based on its deprotonated molecule $[\mathrm{M}-\mathrm{H}]^{-}$at $\mathrm{m} / \mathrm{z} 355.1038$ at $\mathrm{t}_{\mathrm{R}}=13.67 \mathrm{~min}$, which later produced three fragmentation ions in MS/MS analysis at $m / z 285.0984$ [M-H-70] ${ }^{-}$with the loss of $\mathrm{C}_{3} \mathrm{H}_{2} \mathrm{O}_{2}, \mathrm{~m} / z 255.0656$ [M-H-100] ${ }^{-}$with the loss of $\mathrm{C}_{4} \mathrm{H}_{4} \mathrm{O}_{3}$, and $m / z 241.1012$ [M-H-114] ${ }^{-}$with the loss of $\mathrm{C}_{6} \mathrm{H}_{10} \mathrm{O}_{2}$ [48]. 
Additionally, 6-Hydroxyflavanone (Peak 43) was identified at $t_{R}=14.61 \mathrm{~min}$. This compound gives out a deprotonated molecule $[\mathrm{M}-\mathrm{H}]^{-}$at $m / z 239.0713$ and three fragmentation ions in MS/MS analysis at $m / z 211.0628$ [M-H-28 $]^{-}, 197.0602$ [M-H-42] ${ }^{-}$, and $136.0112[\mathrm{M}-\mathrm{H}-103]^{-}$. These fragmentations occurred due to the loss of $\mathrm{CO}, \mathrm{C}_{2} \mathrm{H}_{2} \mathrm{O}$, and $\mathrm{C}_{8} \mathrm{H}_{7}$, respectively [40]. The presence of this compound was confirmed with the available standards.

At $t_{R}=14.98 \mathrm{~min}$, with a deprotonated molecule $[\mathrm{M}-\mathrm{H}]^{-}$at $\mathrm{m} / \mathrm{z} 393.3017$, which later produced three fragmentation ions in MS/MS analysis at $\mathrm{m} / \mathrm{z} 375.2910[\mathrm{M}-\mathrm{H}-18]^{-}, \mathrm{m} / \mathrm{z}$ 361.2715 [M-H-32] $^{-}$and $m / z 353.2982$ [M-H-40] ${ }^{-}$was identified as trihydroxydiprenylisoflavan (Peak 44), as this fragmentation occurred due to the loss of $\mathrm{H}_{2} \mathrm{O}, \mathrm{CH}_{4} \mathrm{O}$, and $\mathrm{C}_{3} \mathrm{H}_{4}$, respectively [49].

Next, 3-hydroxy-3', $4^{\prime}$-dimethoxyflavone (Peak 60) and its isomer (Peak 61) were identified putatively at $t_{R}=16.86$ and $17.02 \mathrm{~min}$. This compound give out to a deprotonated molecule $[\mathrm{M}+\mathrm{H}]^{+}$at $m / z 299.0925$, which later produced three significant fragmentation ions in MS/MS analysis at $m / z 283.0610$ [M+H-16] ${ }^{+}, 267.0578$ [M+H-32] ${ }^{+}$, and $237.0548[\mathrm{M}+\mathrm{H}-62]^{+}$. Each of which occurred due to the loss of one oxygen moiety, loss of $\mathrm{CH}_{4} \mathrm{O}$, and loss of $\mathrm{C}_{2} \mathrm{H}_{6} \mathrm{O}_{2}$, respectively [40]. Additionally, 3-hydroxy-3', $4^{\prime}$-dimethoxyflavone was isolated and elucidated from the leaves of M. calabura by Sufian et al. [12].

At $t_{R}=3.66$ and 3.82 min, myricitrin (Peak 49) and its isomer (Peak 50) were identified with deprotonated molecule $[\mathrm{M}+\mathrm{H}]^{+}$at $\mathrm{m} / z$ 465.1050, produced three significant fragmentation ions in MS/MS analysis at $m / z 447.3480[\mathrm{M}+\mathrm{H}-18]^{+}, 303.0513[\mathrm{M}+\mathrm{H}-162]^{+}$, and $285.0772[\mathrm{M}+\mathrm{H}-180]^{+}$. These fragmentations occur due to the loss of $\mathrm{H}_{2} \mathrm{O}, \mathrm{C}_{6} \mathrm{H}_{10} \mathrm{O}_{5}$, and $\mathrm{C}_{6} \mathrm{H}_{12} \mathrm{O}_{6}$, respectively [40].

\subsubsection{Anthocyanin}

Myrtillin (Peak 8) and its isomer (Peak 9) were identified based on its deprotonated molecule $[\mathrm{M}-\mathrm{H}]^{-}$at $\mathrm{m} / z 464.8049$ at $\mathrm{t}_{\mathrm{R}}=4.05$ and $4.21 \mathrm{~min}$, which later produced three fragmentation ions in MS/MS analysis at $m / z 286.9921$ [M-H-78] $^{-}, 299.0193$ [M-H-166] ${ }^{-}$, and 178.9979 [M-H-286] $]^{-}$. These fragmentations occurred due to the loss of $\mathrm{C}_{3} \mathrm{H}_{10} \mathrm{O}_{2}$, $\mathrm{C}_{6} \mathrm{H}_{14} \mathrm{O}_{5}$, and $\mathrm{C}_{15} \mathrm{H}_{10} \mathrm{O}_{6}$, respectively [40]. This compound was isolated and characterized by Harborne et al. [50] in this plant.

\subsubsection{Chalcone}

At $t_{R}=10.16$ and $12.73 \mathrm{~min}$, chalcone compounds were identified based on its deprotonated molecule $[\mathrm{M}-\mathrm{H}]^{-}$at $\mathrm{m} / z 255.0662$ and the similar fragmentation ions in MS/MS analysis at $m / z 227.0477$ [M-H-28] $]^{-}$due to the loss of $\mathrm{C}_{2} \mathrm{H}_{4}, m / z 213.0526$ [M-H-42] ${ }^{-}$due to the loss of $\mathrm{C}_{2} \mathrm{H}_{2} \mathrm{O}$, and $\mathrm{m} / z 187.0655$ [M-H-68] ${ }^{-}$due to the loss of $\mathrm{C}_{4} \mathrm{H}_{4} \mathrm{O}$. These compounds were identified as isoliquiritigenin (Peak 15) and its isomers (Peak 31) [51]. Isoliquiritigenin was previously isolated and characterized by Hsu et al. [51] in M. calabura species.

\subsubsection{Quinone Derivatives}

Six different quinone derivatives and their isomers, named arbutin, rhein, and lapachol, were tentatively identified throughout the spectrum. At $t_{\mathrm{R}}=10.80$ and $10.96 \mathrm{~min}$, arbutin (Peak 19) and its isomer (Peak 20) with a deprotonated molecule $[\mathrm{M}-\mathrm{H}]^{-}$at $\mathrm{m} / \mathrm{z}$ 271.0613 and three fragmentation ions in MS/MS analysis at $\mathrm{m} / \mathrm{z} 253.0507$ [M-H-18] ${ }^{-}$, 197.0603 [M-H-74] $]^{-}$, and 161.0600 [M-H-110] ${ }^{-}$due to the loss of $\mathrm{H}_{2} \mathrm{O}, \mathrm{C}_{3} \mathrm{H}_{6} \mathrm{O}_{2}$, and $\mathrm{C}_{6} \mathrm{H}_{6} \mathrm{O}_{2}$, respectively [52]. Rhein (Peak 35) and its isomers were tentatively identified at $t_{\mathrm{R}}=13.45,13.92$, and $14.23 \mathrm{~min}$, with its deprotonated molecule at $[\mathrm{M}-\mathrm{H}]^{-}$at $\mathrm{m} / \mathrm{z}$ 282.9547 and three fragmentation ions in MS/MS analysis at $m / z 267.0296$ [M-H-16] ${ }^{-}$with the loss of $\mathrm{CH}_{4}, 239.0353$ [M-H-48] $]^{-}$with the loss of $\mathrm{CH}_{4} \mathrm{O}_{2}$, and 211.0396 [M-H-72] ${ }^{-}$with the loss of $\mathrm{C}_{3} \mathrm{H}_{4} \mathrm{O}_{2}$ [53]. While lapachol (Peak 42) was identified at $\mathrm{t}_{\mathrm{R}}=14.38 \mathrm{~min}$, with its deprotonated molecule at $[\mathrm{M}-\mathrm{H}]^{-}$at $\mathrm{m} / \mathrm{z} 240.9106$, and three fragmentation ions at MS/MS analysis at $\mathrm{m} / \mathrm{z} 223.0756$ [M-H-18] ${ }^{-}, 198.1011$ [M-H-43] $^{-}$, and 186.0566 [M-H-55] ${ }^{-}$due to the loss of $\mathrm{H}_{2} \mathrm{O}, \mathrm{C}_{2} \mathrm{H}_{3} \mathrm{O}$, and $\mathrm{C}_{4} \mathrm{H}_{7}$, respectively [54]. 


\subsubsection{Lactone Derivatives}

One lactone derivative named yangonin (Peak 29) and its isomer (Peak 34) were identified at $t_{\mathrm{R}}=12.71$ and $13.40 \mathrm{~min}$ with deprotonated molecule at $[\mathrm{M}-\mathrm{H}]^{-}$at $\mathrm{m} / \mathrm{z}$ 257.0644. Three similar fragmentation ions in MS/MS analysis includes $\mathrm{m} / \mathrm{z} 239.0710$ [M-H-18] ${ }^{-}$(loss of $\left.\mathrm{H}_{2} \mathrm{O}\right), 213.0919$ [M-H-44] ${ }^{-}$(loss of $\mathrm{CO}_{2}$ ), and 197.0815 [M-H-60] ${ }^{-}$(loss of $\mathrm{C}_{2} \mathrm{H}_{4} \mathrm{O}_{2}$ ) [50].

\subsubsection{Terpene Glycoside}

Geniposide (Peak 10) with a deprotonated molecule at $[\mathrm{M}-\mathrm{H}]^{-}$at $\mathrm{m} / \mathrm{z} 387.1145$ was identified at $t_{R}=6.34 \mathrm{~min}$, with three MS/MS fragmentation ions at $\mathrm{m} / \mathrm{z} 284.0327$ [M-H-103 $]^{-}$, 255.0298 [M-H-132] ${ }^{-}$, and 224.8609 [M-H-162 $]^{-}$. These signals, respectively, corresponded to the loss of $\mathrm{C}_{4} \mathrm{H}_{7} \mathrm{O}_{3}, \mathrm{C}_{5} \mathrm{H}_{8} \mathrm{O}_{4}$, and $\mathrm{C}_{6} \mathrm{H}_{10} \mathrm{O}_{5}$ [55]. Identification of this compound was confirmed by using the authentic standard.

\subsubsection{Alkaloid Derivatives}

Two alkaloid derivatives identified were piceatannol galloylglucoside (Peak 26) with deprotonated molecule at $[\mathrm{M}-\mathrm{H}]^{-}$at $m / z 557.1458$ and narceinone (Peak 47) with deprotonated molecule at $[\mathrm{M}-\mathrm{H}]^{-}$at $\mathrm{m} / \mathrm{z} 457.9947$ at $\mathrm{t}_{\mathrm{R}}=12.36$ and $16.18 \mathrm{~min}$, respectively. Piceatannol galloylglucoside (Peak 26) give out to four fragmentations ions in MS/MS

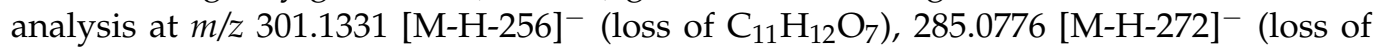
$\mathrm{C}_{11} \mathrm{H}_{12} \mathrm{O}_{8}$ ), 257.3555 [M-H-300] ${ }^{-}$(loss of $\mathrm{C}_{16} \mathrm{H}_{12} \mathrm{O}_{6}$ ), and 201.0187 [M-H-356] ${ }^{-}$(loss of $\mathrm{C}_{15} \mathrm{H}_{16} \mathrm{O}_{10}$ ), while narceinone (Peak 47) give out to three fragmentations ions in MS/MS analysis at $m / z 427.9972$ [M-H-30] $^{-}, 397.9993$ [M-H-59] $^{-}$, and 367.9799 [M-H-90] $^{-}$due to the loss of $\mathrm{CH}_{2} \mathrm{O}, \mathrm{C}_{2} \mathrm{H}_{3} \mathrm{O}_{2}$, and $\mathrm{C}_{2} \mathrm{H}_{2} \mathrm{O}_{4}$, respectively [56,57].

\subsubsection{Sugar}

Sucrose (Peak 2) and its dimer (Peak 1) were identified at $t_{R}=0.94$ and $0.81 \mathrm{~min}$, respectively with deprotonated molecule at $[\mathrm{M}-\mathrm{H}]^{-}$at $\mathrm{m} / \mathrm{z} 341.1090$ and 683.2253. They share a similar fragmentations pattern in MS/MS analysis at $m / z$ 179.0555 [M-H-162] ${ }^{-}$ (loss of $\mathrm{C}_{6} \mathrm{H}_{10} \mathrm{O}_{5}$ ), 161.0443 [M-H-180] $]^{-}$(loss of glucose moiety), and 143.0345 [M-H-198] ${ }^{-}$ (loss of $\mathrm{C}_{6} \mathrm{H}_{14} \mathrm{O}_{7}$ ) [40].

\subsubsection{Ellagitannin Derivative}

Corilagin (Peak 5) was tentatively identified at $t_{R}=1.39 \mathrm{~min}$ with deprotonated molecule at $[\mathrm{M}-\mathrm{H}]^{-}$at $m / z$ 633.0735. The three fragmentations pattern in MS/MS analysis were shown at $m / z 481.1787$ [M-H-152] ${ }^{-}$(loss of $\mathrm{C}_{7} \mathrm{H}_{4} \mathrm{O}_{4}$ ), 313.0568 [M-H-320] ${ }^{-}$(loss of $\left.\mathrm{C}_{14} \mathrm{H}_{8} \mathrm{O}_{9}\right)$, and 169.0137 [M-H-164] ${ }^{-}$(loss of $\left.\mathrm{C}_{20} \mathrm{H}_{16} \mathrm{O}_{13}\right)$ [58]. 
Table 2. Tentative identification of compounds present in $M$. calabura FD leaves extracted with $50 \%$ ethanol.

\begin{tabular}{|c|c|c|c|c|c|c|c|c|c|c|}
\hline Peak No & $t_{R}$ & UV $\lambda$-Max & MF & Exact Mass & $(\mathrm{M}-\mathrm{H})^{-}$ & $(\mathrm{M}+\mathrm{H})^{+}$ & Mass Error & MS/MS Fragment Ions & Tentative Identification & References \\
\hline 1 & 0.81 & $210,274,350,370$ & ND & ND & 683.2253 & - & ND & $341.1091,179.0554,161.0447,143.0340$ & Sucrose dimer & [40] \\
\hline 2 & 0.94 & $210,272,350,370$ & $\mathrm{C}_{12} \mathrm{H}_{22} \mathrm{O}_{11}$ & 342.1162 & 341.1090 & - & 0.0072 & $179.0555,161.0443,143.0345$ & Sucrose & [40] \\
\hline 3 & 1.24 & $208,266,292,350,370$ & $\mathrm{C}_{15} \mathrm{H}_{14} \mathrm{O}_{7}$ & 306.0740 & 305.0668 & - & 0.0072 & $289.0642,245.0440,219.0657,167.0341$ & Epigallocatechin & [40] \\
\hline 4 & 1.36 & 210,272 & $\mathrm{C}_{19} \mathrm{H}_{18} \mathrm{O}_{7}$ & 358.1053 & 357.1195 & - & -0.0142 & $270.8385,224.8610,179.0586$ & $\begin{array}{l}\text { 3'-Hydroxy-7,8,4', } 5^{\prime}- \\
\text { tetramethoxyflavone * }\end{array}$ & [46] \\
\hline 5 & 1.39 & $208,216,276,270$ & $\mathrm{C}_{27} \mathrm{H}_{22} \mathrm{O}_{18}$ & 634.0806 & 633.0735 & - & 0.0071 & $481.1787,313.0568,169.0137$ & Corilagin & [58] \\
\hline 6 & 1.40 & 208,274 & $\mathrm{C}_{15} \mathrm{H}_{14} \mathrm{O}_{7}$ & 306.0740 & 305.0668 & - & 0.0072 & $289.0233,245.0284,219.0655,167.0338$ & Gallocatechin & [40] \\
\hline 7 & 2.42 & 208,356 & $\mathrm{C}_{20} \mathrm{H}_{20} \mathrm{O}_{7}$ & 372.1209 & 371.0986 & - & 0.0223 & $296.8684,240.8795,231.0506$ & $7,8,3^{\prime}, 4^{\prime}, 5^{\prime}$-Pentamethoxyflavone * & [46] \\
\hline 8 & 4.05 & $206,256,350$ & $\mathrm{C}_{21} \mathrm{H}_{21} \mathrm{O}_{12}$ & 465.1033 & 464.8049 & - & -0.7016 & $386.9921,299.0193,178.9979$ & Myrtillin* & [40] \\
\hline 9 & 4.21 & $206,258,350$ & $\mathrm{C}_{21} \mathrm{H}_{21} \mathrm{O}_{12}$ & 465.1033 & 464.8049 & - & -0.7016 & $386.9907,298.9871,178.9980$ & Myrtillin isomer & [40] \\
\hline 10 & 6.34 & $210,272,350,370$ & $\mathrm{C}_{17} \mathrm{H}_{24} \mathrm{O}_{10}$ & 388.1369 & 387.1145 & - & 0.0224 & $284.0327,255.0298,224.8609$ & Geniposide \# & [40] \\
\hline 11 & 8.70 & 222,272 & $\mathrm{C}_{26} \mathrm{H}_{30} \mathrm{O}_{6}$ & 438.2042 & 437.0466 & - & 0.1576 & $296.8747,288.7813,242.8798$ & Hiravanone* & [47] \\
\hline 12 & 9.43 & 222,274 & $\mathrm{C}_{30} \mathrm{H}_{26} \mathrm{O}_{13}$ & 594.1373 & 593.1304 & - & 0.0069 & $447.0935,429.0823,285.0404$ & Buddlenoid A* & [41] \\
\hline 13 & 9.49 & $222,268,314$ & ND & ND & 1187.2678 & - & ND & $593.1306,447.0932,429.0825,285.0408$ & Buddlenoid A dimer & [41] \\
\hline 14 & 9.75 & $222,268,296,374$ & $\mathrm{C}_{30} \mathrm{H}_{26} \mathrm{O}_{13}$ & 594.1373 & 593.1304 & - & 0.0069 & $447.0919,429.0820,285.0406$ & Buddlenoid A isomer & [41] \\
\hline 15 & 10.16 & 222,280 & $\mathrm{C}_{15} \mathrm{H}_{12} \mathrm{O}_{4}$ & 256.0736 & 255.0662 & - & 0.0074 & $227.0477,213.0526,187.0655$ & Isoliquiritigenin * & [51] \\
\hline 16 & 10.47 & 222,294 & $\mathrm{C}_{16} \mathrm{H}_{14} \mathrm{O}_{6}$ & 302.0790 & 301.0721 & - & 0.0069 & $286.0490,269.0465,211.0475$ & 3,5,8-Trihydroxy-7-methoxyflavanone * & [16] \\
\hline 17 & 10.63 & 224,286 & $\mathrm{C}_{16} \mathrm{H}_{14} \mathrm{O}_{6}$ & 302.0790 & 301.0721 & - & 0.0069 & $286.0489,269.0461,211.0474$ & Trihydroxymethoxyflavanone isomer & [16] \\
\hline 18 & 10.78 & 222,294 & $\mathrm{C}_{16} \mathrm{H}_{14} \mathrm{O}_{6}$ & 302.0790 & 301.0721 & - & 0.0069 & $286.0492,269.0452,211.0475$ & Trihydroxymethoxyflavanone isomer & [16] \\
\hline 19 & 10.80 & 222,294 & $\mathrm{C}_{12} \mathrm{H}_{16} \mathrm{O}_{7}$ & 272.0896 & 271.0613 & - & 0.0283 & $253.0507,197.0603,161.0600$ & Arbutin & [52] \\
\hline 20 & 10.96 & $224,276,296,376$ & $\mathrm{C}_{12} \mathrm{H}_{16} \mathrm{O}_{7}$ & 272.0896 & 271.0613 & - & 0.0283 & $253.0509,197.0603,161.0600$ & Arbutin isomer & [52] \\
\hline 23 & 11.17 & 224,306 & $\mathrm{C}_{21} \mathrm{H}_{20} \mathrm{O}_{11}$ & 448.1006 & 447.2237 & - & -0.1231 & $301.0923,285.0311,245.0662$ & Quercitrin isomer & [40] \\
\hline 24 & 11.87 & 224,282 & $\mathrm{C}_{15} \mathrm{H}_{10} \mathrm{O}_{6}$ & 286.0477 & 285.0401 & - & 0.0076 & $269.0448,216.9897,119.0491$ & Kaempferol \# & [40] \\
\hline 25 & 12.30 & $224,270,292,312$ & $\mathrm{C}_{25} \mathrm{H}_{28} \mathrm{O}_{6}$ & 424.1886 & 423.0928 & - & 0.0958 & $353.2442,287.6386,251.0923$ & 6,8-Diprenyleriodictyol * & [47] \\
\hline 26 & 12.36 & 224,290 & $\mathrm{C}_{27} \mathrm{H}_{26} \mathrm{O}_{13}$ & 558.4875 & 557.1458 & - & 0.3417 & $301.1331,285.0776,257.3555,201.0187$ & Piceatannol galloylglucoside & [57] \\
\hline 27 & 12.50 & 224,286 & $\mathrm{C}_{17} \mathrm{H}_{14} \mathrm{O}_{7}$ & 330.0740 & 329.0672 & - & 0.0068 & $314.0419,299.0198,285.0399$ & Cirsiliol & [40] \\
\hline 28 & 12.66 & $224,292,376$ & $\mathrm{C}_{17} \mathrm{H}_{14} \mathrm{O}_{7}$ & 330.0740 & 329.0670 & - & 0.0070 & $314.0435,299.0198,285.0421$ & Cirsiliol isomer & [40] \\
\hline 29 & 12.71 & $224,292,376$ & $\mathrm{C}_{15} \mathrm{H}_{14} \mathrm{O}_{4}$ & 258.0892 & 257.0644 & - & 0.0248 & $239.0710,213.0919,197.0815$ & Yangonin & [50] \\
\hline 30 & 12.72 & $224,292,376$ & $\mathrm{C}_{27} \mathrm{H}_{28} \mathrm{O}_{14}$ & 576.1479 & 575.1748 & - & -0.0269 & $513.0697,341.1581,269.1393,231.1236$ & Vitexin hydroxymethylglutarate & [43] \\
\hline 31 & 12.73 & $224,282,332,374$ & $\mathrm{C}_{15} \mathrm{H}_{12} \mathrm{O}_{4}$ & 256.0736 & 255.0662 & - & 0.0074 & $227.0711,213.0549,187.0634$ & Isoliquiritigenin isomer & [51] \\
\hline 32 & 12.96 & $224,332,374$ & $\mathrm{C}_{18} \mathrm{H}_{16} \mathrm{O}_{7}$ & 344.0896 & 343.0823 & - & 0.0073 & $327.0524,313.0357,256.9828$ & $\begin{array}{l}\text { 8, } 3^{\prime} \text {-Dihydroxy-7, } 4^{\prime}, 5^{\prime}- \\
\text { trimethoxyflavone * }\end{array}$ & [46] \\
\hline 33 & 13.31 & $224,280,378$ & $\mathrm{C}_{17} \mathrm{H}_{16} \mathrm{O}_{5}$ & 300.0998 & 299.0196 & - & 0.0802 & $284.0326,269.0457,255.0300,239.0348$ & Dimethoxyhydroxyflavanone & [40] \\
\hline 34 & 13.40 & $218,274,366$ & $\mathrm{C}_{15} \mathrm{H}_{14} \mathrm{O}_{4}$ & 258.0892 & 257.0644 & - & 0.0248 & $239.0712,213.0915,197.0597$ & Yangonin isomer & [50] \\
\hline 35 & 13.45 & $224,272,360,374$ & $\mathrm{C}_{15} \mathrm{H}_{8} \mathrm{O}_{6}$ & 284.0321 & 282.9547 & - & 0.0774 & $267.0296,239.0353,211.0396$ & Rhein & [53] \\
\hline 36 & 13.47 & $222,268,312,360$ & $\mathrm{C}_{17} \mathrm{H}_{16} \mathrm{O}_{5}$ & 300.0998 & 299.0196 & - & 0.0802 & $284.0326,269.0816,255.0304,239.0346$ & Dimethoxyhydroxyflavanone isomer & [40] \\
\hline 37 & 13.63 & $224,278,356,376$ & $\mathrm{C}_{15} \mathrm{H}_{12} \mathrm{O}_{6}$ & 288.0634 & 287.0539 & - & 0.0095 & $271.0607,269.0723,216.9894,119.0077$ & Dihydrokaempferol & [40] \\
\hline 38 & 13.67 & $224,286,376$ & $\mathrm{C}_{20} \mathrm{H}_{20} \mathrm{O}_{6}$ & 356.1260 & 355.1038 & - & 0.0222 & $285.0948,255.0656,241.1012$ & Kievitone & [48] \\
\hline 39 & 13.92 & $224,274,352$ & $\mathrm{C}_{15} \mathrm{H}_{8} \mathrm{O}_{6}$ & 284.0321 & 282.9547 & - & 0.0774 & $267.0282,239.0348,211.0397$ & Rhein isomer & [53] \\
\hline 40 & 14.03 & $224,268,346$ & $\mathrm{C}_{17} \mathrm{H}_{14} \mathrm{O}_{6}$ & 314.0790 & 313.0719 & - & 0.0071 & $\begin{array}{c}299.0505,285.0284,255.0299,227.0350 \\
213.0395\end{array}$ & Velutin & [40] \\
\hline
\end{tabular}


Table 2. Cont.

\begin{tabular}{|c|c|c|c|c|c|c|c|c|c|c|}
\hline Peak No & $t_{R}$ & UV $\lambda$-Max & MF & Exact Mass & $(\mathrm{M}-\mathrm{H})^{-}$ & $(\mathrm{M}+\mathrm{H})^{+}$ & Mass Error & MS/MS Fragment Ions & Tentative Identification & References \\
\hline 41 & 14.23 & 224,378 & $\mathrm{C}_{15} \mathrm{H}_{8} \mathrm{O}_{6}$ & 284.0321 & 282.9547 & - & 0.0774 & $267.0306,239.0348,211.0396$ & Rhein isomer & [53] \\
\hline 42 & 14.38 & $224,286,362,376$ & $\mathrm{C}_{15} \mathrm{H}_{14} \mathrm{O}_{3}$ & 242.0943 & 240.9106 & - & 0.1837 & $223.0756,198.1011,186.0566$ & Lapachol & [54] \\
\hline 43 & 14.61 & 224,376 & $\mathrm{C}_{15} \mathrm{H}_{12} \mathrm{O}_{3}$ & 240.0786 & 239.0713 & - & 0.0073 & $211.0628,197.0602,136.0112$ & 6-Hydroxyflavanone \# & [40] \\
\hline 44 & 14.98 & $226,274,312,378$ & $\mathrm{C}_{25} \mathrm{H}_{30} \mathrm{O}_{4}$ & 394.5033 & 393.3017 & - & 0.2016 & $375.2910,361.2715,353.2982$ & Trihydroxydiprenylisoflavan & [49] \\
\hline 45 & 15.01 & $220,274,316$ & $\mathrm{C}_{17} \mathrm{H}_{14} \mathrm{O}_{6}$ & 314.0790 & 313.0719 & - & 0.0071 & $\begin{array}{c}\text { 299.0490, 285.0284, } 255.0299,227.0336 \\
213.0398\end{array}$ & Velutin isomer & [40] \\
\hline 46 & 15.19 & $224,270,326,374$ & $\mathrm{C}_{17} \mathrm{H}_{14} \mathrm{O}_{6}$ & 314.0790 & 313.0719 & - & 0.0071 & $\begin{array}{c}299.0466,285.0287,255.0299,227.0347 \\
213.0396\end{array}$ & Velutin isomer & [40] \\
\hline 47 & 16.18 & 216,270 & $\mathrm{C}_{23} \mathrm{H}_{25} \mathrm{NO}_{9}$ & 459.4459 & 457.9947 & - & 0.4512 & 427.9972, 397.9993, 367.9799 & Narceinone & [56] \\
\hline 49 & 3.66 & $208,254,356,376$ & $\mathrm{C}_{21} \mathrm{H}_{20} \mathrm{O}_{12}$ & 464.0955 & - & 465.1050 & -0.0095 & $447.3480,303.0513,285.0772$ & Myricitrin & [40] \\
\hline 50 & 3.82 & $208,254,356,376$ & $\mathrm{C}_{21} \mathrm{H}_{20} \mathrm{O}_{12}$ & 464.0955 & - & 465.1050 & -0.0095 & $447.3459,303.0511,285.0771$ & Myricitrin isomer & [40] \\
\hline 51 & 9.68 & $222,296,374,386$ & $\mathrm{C}_{22} \mathrm{H}_{18} \mathrm{O}_{11}$ & 458.0849 & - & 459.0942 & -0.0093 & $321.0591,289.0771,275.0818$ & Epigallocatechin gallate & [40] \\
\hline 52 & 12.58 & $222,294,344,378$ & $\mathrm{C}_{16} \mathrm{H}_{12} \mathrm{O}_{7}$ & 316.0583 & - & 317.0671 & -0.0088 & $301.0973,285.0734,245.1063$ & Rhamnetin & [40] \\
\hline 53 & 13.00 & $226,292,326$ & $\mathrm{C}_{22} \mathrm{H}_{22} \mathrm{O}_{9}$ & 430.1260 & - & 431.1330 & -0.0070 & $\begin{array}{c}\text { 269.1334, 254.0331, 227.0704, 213.0568, } \\
\text { 201.0357 }\end{array}$ & Ononin & [40] \\
\hline 54 & 13.13 & $224,274,376$ & $\mathrm{C}_{15} \mathrm{H}_{10} \mathrm{O}_{4}$ & 254.0579 & - & 255.0661 & -0.0082 & $227.0694,213.0553,200.9240$ & Daidzein \# & [40] \\
\hline 55 & 13.29 & $224,280,378$ & $\mathrm{C}_{15} \mathrm{H}_{10} \mathrm{O}_{4}$ & 254.0579 & - & 255.0661 & -0.0082 & $227.0668,213.0560,200.9234$ & Daidzein isomer & [40] \\
\hline 56 & 14.38 & $224,282,356,378$ & $\mathrm{C}_{15} \mathrm{H}_{10} \mathrm{O}_{5}$ & 270.0528 & - & 271.0611 & -0.0083 & $254.0868,227.0920,213.0558,201.0650$ & $3^{\prime}$-Hydroxydaidzein * & [44] \\
\hline 57 & 14.78 & 224,338 & $\mathrm{C}_{15} \mathrm{H}_{10} \mathrm{O}_{5}$ & 270.0528 & - & 271.0611 & -0.0083 & $254.0666,227.0918,213.0557,201.0810$ & Hydroxydaidzein isomer & [44] \\
\hline 58 & 16.13 & $226,272,378$ & $\mathrm{C}_{16} \mathrm{H}_{12} \mathrm{O}_{4}$ & 268.0736 & - & 269.0819 & -0.0083 & $254.0582,227.0666,213.0548,201.0915$ & Formononetin \# & [40] \\
\hline 60 & 16.86 & 226,270 & $\mathrm{C}_{17} \mathrm{H}_{14} \mathrm{O}_{5}$ & 298.0841 & - & 299.0925 & -0.0084 & 283.0610, 267.0578, 237.0548 & 3-Hydroxy-3', $4^{\prime}$-dimethoxyflavone * & [40] \\
\hline 61 & 17.02 & 226 & $\mathrm{C}_{17} \mathrm{H}_{14} \mathrm{O}_{5}$ & 298.0841 & - & 299.0925 & -0.0084 & $283.0611,267.0571,237.0637$ & Hydroxydimethoxyflavone isomer & [40] \\
\hline
\end{tabular}




\subsection{UHPLC Absolute Quantification}

Six standard compounds named geniposide, daidzein, quercitrin, kaempferol, formononetin, and 6-hydroxyflavanone that were previously identified by using UHPLCESI-MS/MS technique, were subjected to UHPLC quantification to determine the absolute amount of each standard in the most active extract. The result in Table 3 shows the metabolites content in FD M. calabura leaves extracted with 50\% ethanol, ranging from $56.58 \pm 0.28$ to $650.01 \pm 0.12 \mu \mathrm{g} / \mathrm{mg}$ of extract. The highest contents of metabolites in the extract were in the following order geniposide, daidzein, quercitrin, 6-hydroxyflavanone, kaempferol, and formononetin.

Table 3. Concentration of metabolites in M. calabura FD leaves extracted with $50 \%$ ethanol.

\begin{tabular}{cc}
\hline Metabolites & Concentration $(\mu \mathrm{g} / \mathbf{m g}$ of Extract) \\
\hline Geniposide & $650.01 \pm 0.12$ \\
Daidzein & $231.65 \pm 0.31$ \\
Quercitrin & $223.24 \pm 0.59$ \\
Kaempferol & $75.22 \pm 0.72$ \\
Formononetin & $56.58 \pm 0.28$ \\
6-Hydroxyflavanone & $196.43 \pm 0.28$ \\
\hline
\end{tabular}

Each of these metabolites may contribute to the anti-hyperglycemic effect of M. calabura leaves. For example, geniposide plays an important role in reducing glycogenolysis process through impairment of hepatic glycogen phosphorylase and glucose-6-phosphatase activity, as well as their protein expression in high fat diet-streptozotocin (STZ) induced diabetic mice [18]. On the other hand, daidzein helps to increase the mRNA level in the $\beta$-cells to exert more insulin production, as well as restoring the glucose metabolic enzyme activities in daidzein-supplemented non-obese diabetic mice [19]. In addition, one of the quercetin derivatives has proven to have a protective effect on the intact $\beta$-cells of the islets of Langerhans by inhibiting lipid peroxidation, as well as its ability to scavenge free radicals from STZ-induced oxidative stress in STZ-induced diabetic rats [20]. Although no research has been conducted regarding the proficiency of 6-hydroxyflavanone on directly reducing the blood glucose level, there are some studies that have demonstrated the electron donating ability of 6-hydroxyflavanone to scavenge free radicals induced by 2,2-diphenyl-1-picrylhydrazyl in in vitro antioxidant study [21,59]. Besides that, kaempferol, another flavonoid-type compound that was identified and quantified, also reportedly shows hypoglycemic effect by lowering the levels of glycoprotein in the liver and increment of insulin production, as well as enhancement of glucose utilization in STZ-induced rats [22]. Formononetin helps in the activation of peroxisome proliferatoractivated receptor (PPAR- $\gamma$ ) genes in liver, which, in turn, regulates the blood glucose level, the cell surface receptor protein (FAS) may not induce the cleavage of SREBP-1C site in stimulating lipid synthesis due to an antagonistic interaction between formononetin and PPAR- $\gamma$ genes [23]. Therefore, these identified metabolites were quantified based on its positive attributes in lowering the blood glucose level, either through in vivo or in vitro study, that could potentially influenced the hypoglycemic aptitude of $M$. calabura leaves.

\section{Materials and Methods}

\subsection{Chemicals and Reagents}

LCMS grade formic acid, methanol, acetonitrile, water, dimethyl sulfoxide (DMSO), sodium phosphate buffer, and absolute ethanol were supplied by Thermo Fisher Scientific (Waltham, MA, USA). Other chemicals including p-nitrophenyl- $\alpha$-D-glucopyranose (PNPG), $\alpha$-glucosidase enzyme, $\alpha$-amylase enzyme, glycine, 3,5-dinitrosalicylic acid (DNS), potato starch, and sodium phosphate buffered saline (PBS) were purchased from Sigma Aldrich (St. Louis, MO, USA). All the standard compounds including acarbose, quercetin, daidzein, quercitrin, kaempferol, formononetin, 6-hydroxyflavanone, and geniposide were purchased from Acros Organics (Geel, Belgium) with $>98 \%$ purity. 


\subsection{Plant Materials}

The fresh M. calabura were harvested from Universiti Putra Malaysia's Mosque. Number of voucher specimen (SK 3345/18) was deposited by a botanist (Dr. Mohd Firdaus Ismail) in the herbarium of Institute of Bioscience, Universiti Putra Malaysia. The leaves of five different trees of $M$. calabura were harvested and separated into three drying processes, namely oven-drying (OD), air-drying (AD), and freeze-drying (FD). The fresh leaves were assigned at $40^{\circ} \mathrm{C}$ in a convention oven (Protech, Seri Kembangan, Malaysia), for a duration of 10 days for $\mathrm{OD}$ processed leaves. On the other hand, for the AD sample, the leaves were dried at $37^{\circ} \mathrm{C}$ for the duration of 2 weeks. As for the FD sample, the leaves were stored for 4 days in $-80^{\circ} \mathrm{C}$ freezer (Haier, Surrey, UK) prior to 3 days FD (LabConco, Kansas City, MO, USA). All samples were confirmed to absolute dryness, as their constant weight was achieved before grinding process started. The ground samples were then stored at $2-7^{\circ} \mathrm{C}$ in airtight container until further analysis. Total $5 \mathrm{~g}$ of each ground leaves was soaked and sonicated in $100 \mathrm{~mL}$ of 0,50 , and $100 \%$ ethanol:water ratio, respectively, for $60 \mathrm{~min}$ by using ultrasonic bath sonicator (Kudos, Shanghai, China). The Whatman filter paper no. 1 was used to filter the mixture and the filtered mixture was concentrated under controlled temperature at $40^{\circ} \mathrm{C}$ by using a rotatory evaporator (Buchi LaboratoriumsTechnik, Flawil, Switzerland). To ensure complete dryness, all extracts were then lyophilized in a freeze dryer (LabConco, Kansas City, MO, USA) and subsequently stored at $-20^{\circ} \mathrm{C}$ until further analysis.

\subsection{In Vitro Anti-Diabetic Activity}

\subsection{1. $\alpha$-Glucosidase Inhibition Assay}

The $\alpha$-glucosidase inhibition activity assay has been conducted according to the demonstrated method with modifications [60]. The PNPG in $50 \mathrm{mM}$ phosphate buffer ( $\mathrm{pH}$ 6.5) has been used as the substrate, which was comparable to the intestinal fluid. Next, sample extracts were prepared at $200 \mu \mathrm{g} / \mathrm{mL}$ and 6 serial dilutions were done. In the 96-well plate, a reaction consisting of $130 \mu \mathrm{L}$ of $30 \mathrm{mM}$ phosphate buffer, $10 \mu \mathrm{L}$ of enzyme, and $10 \mu \mathrm{L}$ of extracts was incubated at $37^{\circ} \mathrm{C}$ for $5 \mathrm{~min}$. Then, $50 \mu \mathrm{L}$ of substrate was added in the reaction and was further incubated at $37^{\circ} \mathrm{C}$ for another $15 \mathrm{~min}$. Next, $50 \mu \mathrm{L}$ of $2 \mathrm{M}$ glycine ( $\mathrm{pH} 10$ ) was then added to stop the reaction. The absorbance was measured by using a spectrophotometer (Spectramax PLUS, San Jose, CA, USA) at $405 \mathrm{~nm}$ wavelength. The $\alpha$-glucosidase inhibitory activity was calculated using the equation; [(An - As) $/ \mathrm{An}] \times 100 \%$, where An is the difference in absorbance of the negative control and all the blanks, and As is the difference in absorbance of the sample and all the blanks. The $\alpha$-glucosidase inhibitory activity was expressed as $\mathrm{IC}_{50}$ value $(\mu \mathrm{g} / \mathrm{mL})$ to represent M. calabura extract concentration that was needed to inhibit the enzyme activity by $50 \%$. Quercetin was tested and used as positive control.

\subsection{2. $\alpha$-Amylase Inhibition Assay}

The $\alpha$-amylase inhibition activity assay was carried out based on the demonstrated method with modifications [32]. In a 96-well plate, a reaction mixture containing $50 \mu \mathrm{L}$ of $100 \mathrm{mM}$ phosphate buffer at $\mathrm{pH} 6.8,10 \mu \mathrm{L}$ of $2 \mathrm{U} / \mathrm{mL}$ porcine $\alpha$-amylase, and $20 \mu \mathrm{L}$ of varying concentrations of the extract $(0.04,0.07,0.14,0.28$, and $0.56 \mathrm{mg} / \mathrm{mL})$ was incubated at $37^{\circ} \mathrm{C}$ for $20 \mathrm{~min}$. Then, $20 \mu \mathrm{L}$ of substrate $(1 \%$ starch dissolved in $100 \mathrm{mM}$ phosphate buffer at $\mathrm{pH}$ 6.8) was added, and the mixture was further incubated at $37^{\circ} \mathrm{C}$ for $30 \mathrm{~min}$. The reaction was then stopped by adding $100 \mu \mathrm{L}$ of the DNS color reagent and boiled for $10 \mathrm{~min}$. The absorbance was measured by using a spectrophotometer (Spectramax PLUS, San Jose, CA, USA) at $540 \mathrm{~nm}$ wavelength. The $\alpha$-amylase inhibitory activity has been calculated using the equation; [(An - As) $/ \mathrm{An}] \times 100 \%$, where An is the difference in absorbance of the negative control and all the blanks, and As is the difference in absorbance of the sample and all the blanks. The $\alpha$-amylase inhibitory activity was expressed as $\mathrm{IC}_{50}(\mu \mathrm{g} / \mathrm{mL})$. Acarbose was tested and employed as a positive control in each plate of $\alpha$-amylase activity. 


\subsection{UHPLC-ESI-MS/MS Analysis}

The sample preparation for UHPLC-ESI-MS/MS analysis was prepared based on the reported method with modifications [36]. The most active extract (4 mg) was dissolved in $2 \mathrm{~mL}$ of LCMS-grade methanol and filtered through a $0.22 \mu \mathrm{m}$ filter prior to $20.0 \mu \mathrm{L}$ injection to the UHPLC-ESI-MS/MS analysis. The analysis was performed using an Dionex Ultimate 3000 UHPLC coupled with Q Exactive ${ }^{\mathrm{TM}}$ Focus Orbitrap mass spectrometer (Thermo Fisher Scientific, Bremen, Germany) equipped with a binary pump, vacuum degasser, temperature-controlled autosampler, diode array detector (200-600 nm range; $5 \mathrm{~nm}$ bandwidth), and a heated electrospray ionization source. The separation was conducted on a Waters Acquity UPLC HSS T3 column $(1.8 \mu \mathrm{m}, 2.1 \times 100 \mathrm{~mm})$ (Waters Corp, Milford, MA, USA). The gradient solvent system was then commenced from 95:5-0:100 $(v / v)$ of water with $0.1 \%$ formic acid: acetonitrile with $0.1 \%$ formic acid over $39 \mathrm{~min}$, with a flow rate of $0.25 \mathrm{~mL} / \mathrm{min}$. Negative and positive ion modes were acquired and recorded on $\mathrm{Q}$ Exactive $^{\mathrm{TM}}$ Focus Orbitrap mass spectrometer (Thermo Fisher Scientific, Bremen, Germany). The MSn analytical conditions were as follows: spray volt-pressure $-3.6 \mathrm{kV}$; equipment temperature, $37.8^{\circ} \mathrm{C}$; capillary temperature, $300^{\circ} \mathrm{C}$; auxiliary gas at 8 units; sheath gas at 50 units; scan range $m / z$ 150-1200, data acquisition frequency at $12 \mathrm{~Hz}$, and collision-induced dissociation energy was adjusted to $30 \%$. The data was recorded and processed using the Thermo Xcalibur Qual Browser software 4.0 (Thermo Fisher Scientific, Bremen, Germany).

\subsection{Absolute Quantification from FD Leaves Extracted with 50\% Ethanol by UHPLC}

The most active extract was also subjected to absolute quantification for several phenolics named daidzein, quercitrin, kaempferol, formononetin, and 6-hydroxyflavanone, as well as a terpene glycoside, geniposide. The sample preparation for UHPLC analysis was according to the reported method with slight adjustment [36]. The active extract (10 mg) of the M. calabura was dissolved in $2 \mathrm{~mL}$ of LCMS-grade methanol and filtered through a $0.22 \mu \mathrm{m}$ filter prior to $2.0 \mu \mathrm{L}$ injection to the UHPLC analysis. The analysis was performed using a Waters Acquity UHPLC (Waters Corp, Milford, MA, USA) equipped with a binary pump, vacuum degasser, temperature-controlled autosampler, column heater, and 2998 photodiode array (PDA) detector (200-600 $\mathrm{nm}$ range; $5 \mathrm{~nm}$ bandwidth). The separation was conducted on a Waters Acquity UPLC HSS T3 column $(1.8 \mu \mathrm{m}, 2.1 \times 150 \mathrm{~mm})$ (Waters Corp, Milfor, MA, USA) with the same gradient solvent system mentioned in profiling section, where the gradient solvent system was commenced from 95:5-0:100 $(v / v)$ of water with $0.1 \%$ FA:acetonitrile with $0.1 \%$ FA over $39 \mathrm{~min}$ with a flow rate of $0.25 \mathrm{~mL} / \mathrm{min}$. The detection wavelength was set at $254 \mathrm{~nm}$. The data was evaluated and processed by using the Waters Empower Chromatography Data System software. The metabolite contents in the plant extract were calculated, based on the area under the peak, and expressed as $\mu \mathrm{g} / \mathrm{mg}$ of plant extract.

The quantification method was validated according to International Council of Harmonization (ICH) tripartite guidelines [61] based on the following criteria:

- Specificity: the retention time of the standards and extract are complementary with no contaminants or impurities detected in the eluent, with the equal volume $(2.0 \mu \mathrm{L})$ of sample, standards, and solvent injected into the chromatography system.

- Repeatability precision: all the relative standard deviation (RSD) were $<2 \%$, indicating high precision. The repeatability precision test was acquired by three-times injections at three concentration levels $(5,20$, and $40 \mu \mathrm{g} / \mathrm{mL}$ ) for each standard (daidzein, quercitrin, kaempferol, formononetin, 6-hydroxyflavanone, and geniposide).

- Linearity and range: the calibration curve was obtained by three data points at 5 , 20 , and $40 \mu \mathrm{g} / \mathrm{mL}$. Each calibration curve was determined by the averaging triplicate value of each concentration. Table 4 shows the concentration range, regression equation, and correlation coefficient $\left(R^{2}\right)$. 
- Limit of detection (LOD) and limit of quantification (LOQ) were determined by calculating the signal:noise ratio, established at 3.3:1 (LOD) and 10:1 (LOQ), based on the calibration curve with the following formula:

$$
\begin{aligned}
& \mathrm{LOD}=(\mathrm{SD} \times 3.3) / \mathrm{M} \\
& \mathrm{LOQ}=(\mathrm{SD} \times 10) / \mathrm{M}
\end{aligned}
$$

where $\mathrm{SD}$ is the standard deviation of the response, and $\mathrm{M}$ is the slope of calibration curve. Table 4 demonstrates the LOD and LOQ value for the six tested standards.

Table 4. Linearity, LOD, and LOQ values of the UHPLC method for the standard compounds.

\begin{tabular}{cccccc}
\hline Standards & $\begin{array}{c}\text { Concentration } \\
\text { Range }(\boldsymbol{\mu g} / \mathbf{m L})\end{array}$ & Regression Equation & $\begin{array}{c}\text { Correlation } \\
\text { Coefficient }\left(\mathbf{R}^{\mathbf{2}}\right)\end{array}$ & $\begin{array}{c}\text { LOD } \\
(\boldsymbol{\mu g} / \mathbf{m L})\end{array}$ & $\begin{array}{c}\text { LOQ } \\
(\boldsymbol{\mu g} / \mathbf{m L})\end{array}$ \\
\hline Daidzein & $5.1592-40.2551$ & $\mathrm{Y}=2.67 \times 10^{4} \mathrm{X}-2.33 \times 10^{4}$ & 0.999 & 0.10 & 0.30 \\
Quercitrin & $4.7603-39.9357$ & $\mathrm{Y}=1.83 \times 10^{4} \mathrm{X}-2.45 \times 10^{4}$ & 0.999 & 0.04 & 0.11 \\
Kaempferol & $5.4330-40.6827$ & $\mathrm{Y}=1.82 \times 10^{4} \mathrm{X}-3.33 \times 10^{4}$ & 0.999 & 0.17 & 0.52 \\
Formononetin & $5.1813-40.1937$ & $\mathrm{Y}=2.05 \times 10^{4} \mathrm{X}-1.45 \times 10^{4}$ & 0.999 & 0.19 & 0.56 \\
6-Hydroxyflavanone & $5.1507-40.1779$ & $\mathrm{Y}=1.58 \times 10^{4} \mathrm{X}-4.56 \times 10^{4}$ & 0.999 & 0.03 & 0.10 \\
Geniposide & $5.7511 \sim 40.7790$ & $\mathrm{Y}=4.16 \times 10^{3} \mathrm{X}-6.01 \times 10^{3}$ & 0.999 & 0.32 & 0.96 \\
\hline
\end{tabular}

\subsection{Statistical Analysis}

The results of the five biological replicates were expressed in mean \pm standard deviation. The statistical analysis was done by using Minitab software (Version 16, Minitab Inc, State College, PA, USA), while the significant difference in the results was determined by analysis of variance (ANOVA) with post hoc Tukey pairwise multiple-comparisons test $(p<0.05$, significant).

\section{Conclusions}

In conclusion, M. calabura leaves, extracted with $50 \%$ ethanol and dried by using FD method, were revealed to be the best condition to extract the anti-diabetic metabolites. A total of sixty-one compounds were tentatively identified in the active extract by using UHPLC-ESI-MS/MS technique, including five catechin derivatives, five types of kaempferol derivatives, three types of quercetin derivatives, one apigenin derivative compound, three types of luteolin derivatives, seven types of daidzein derivatives, nineteen types of other flavonoids, two types of anthocyanin compounds, two types of chalcone compounds, six types of quinone derivatives, two types of lactones derivatives, two types of alkaloid derivatives, two types of sugar, one terpene glycoside, and one ellagitannins derivative. The highest contents of metabolites in the active extract were in the following order: geniposide, daidzein, quercitrin, 6-hydroxyflavanone, kaempferol, and formononetin. Hence, this study suggests that, with the incorporation of the FD method, M. calabura leaves when extracted with $50 \%$ ethanol, can play a significant role as a potential for the development of naturally derived herbal medicinal components that not only help to inhibit diabetes related complications but also impedes toxic side effects of synthetic anti-diabetic drugs.

Author Contributions: Conceptualization, F.A., N.S.R. and A.A.; methodology, F.A. and N.K.Z.Z.; software, N.K.Z.Z.; validation, F.A. and N.K.Z.Z.; formal analysis, N.K.Z.Z.; investigation, N.K.Z.Z.; resources, F.A.; data curation, N.K.Z.Z.; writing—original draft preparation, N.K.Z.Z.; writing—review and editing, F.A. and N.K.Z.Z.; visualization, F.A.; supervision, F.A., N.S.R. and A.A.; project administration, F.A.; funding acquisition, F.A., N.S.R. and A.A. All authors have read and agreed to the published version of the manuscript.

Funding: This research was funded by Universiti Putra Malaysia, (UPM/700/2/1/GPB/2017/9597400) provided under Putra High Impact Grant Scheme. 
Institutional Review Board Statement: Not applicable.

Informed Consent Statement: Not applicable.

Data Availability Statement: The data are available within this article.

Acknowledgments: The authors wish to thank Universiti Putra Malaysia for providing the facilities.

Conflicts of Interest: The authors declare no conflict of interest.

Sample Availability: Samples of the compounds are not available from the authors.

\section{References}

1. Moini, J. Pathophysiology of diabetes. In Epidemiology of Diabetes; Elsevier: Oxford, UK, 2019; pp. $25-43$.

2. Rajendiran, D.; Packirisamy, S.; Gunasekaran, K. A review on role of antioxidants in diabetes. Asian J. Pharm. Clin. Res. 2018, 11, 48-53. [CrossRef]

3. Chandran, A.; Abdullah, M.N.; Abdul, F. National Diabetes Registry Report 2013-2019; Ministry of Health Malaysia: Putrajaya, Malaysia, 2019; pp. 1-34.

4. Janani, C.; Kumari, B.D.R. PPAR gamma gene-A review. Diabetes Metab. Syndr. Clin. Res. Rev. 2014, 9, 46-50. [CrossRef]

5. Sola, D.; Rossi, L.; Piero, G.; Schianca, C.; Maffioli, P.; Bigliocca, M.; Mella, R.; Corlianò, F.; Fra, G.P.; Bartoli, E.; et al. Sulfonylureas and their use in clinical practice. Arch. Med. Sci. 2015, 4, 840-848. [CrossRef]

6. Thrasher, J. Pharmacologic management of type 2 diabetes mellitus: Available therapies. Am. J. Med. 2017, 130, 4-17. [CrossRef] [PubMed]

7. Herman, G.A.; Stevens, C.; Van Dyck, K.; Bergman, A.; Yi, B.; De Smet, M.; Snyder, K.; Hilliard, D.; Tanen, M.; Tanaka, W.; et al. Pharmacokinetics and pharmacodynamics of sitagliptin, an inhibitor of dipeptidyl peptidase IV, in healthy subjects: Results from two randomized, double-blind, placebo-controlled studies with single oral doses. Clin. Pharmacol. Ther. 2005, 78, 675-688. [CrossRef]

8. Murai, A.; Iwamura, K.; Takada, M.; Ogawa, K.; Usui, T.; Okumura, J.I. Control of postprandial hyperglycaemia by galactosyl maltobionolactone and its novel anti-amylase effect in mice. Life Sci. 2002, 71, 1405-1415. [CrossRef]

9. Tuomilehto, J.; Pohjola, M.; Lindström, J.; Aro, A. Acarbose and nutrient intake in non-insulin dependent diabetes mellitus. Diabetes Res. Clin. Pract. 1994, 26, 215-222. [CrossRef]

10. Mohamad-Yusof, M.I.; Salleh, M.Z.; Kek, T.L.; Ahmat, N.; Nik-Azmin, N.F.; Zakaria, Z.A. Activity-guided isolation of bioactive constituents with antinociceptive activity from Muntingia calabura L. leaves using the formalin test. Evid. Based Complement. Altern. Med. 2013, 2013, 715074. [CrossRef] [PubMed]

11. Balan, T.; Sani, M.H.M.; Mumtaz-Ahmad, S.H.; Suppaiah, V.; Mohtarrudin, N.; Zakaria, Z.A. Antioxidant and anti-inflammatory activities contribute to the prophylactic effect of semi-purified fractions obtained from the crude methanol extract of Muntingia calabura leaves against gastric ulceration in rats. J. Ethnopharmacol. 2015, 164, 1-15. [CrossRef]

12. Sufian, A.S.; Ramasamy, K.; Ahmat, N.; Zakaria, Z.A.; Yusof, M.I.M. Isolation and identification of antibacterial and cytotoxic compounds from the leaves of Muntingia calabura L. J. Ethnopharmacol. 2013, 146, 198-204. [CrossRef]

13. Zakaria, Z.A.; Mohamed, A.M.; Mohd-Jamil, N.S.; Rofiee, M.S.; Hussain, M.K.; Sulaiman, M.R.; Teh, L.K.; Salleh, M.Z. In vitro antiproliferative and antioxidant activities of the extracts of Muntingia calabura leaves. Am. J. Chin. Med. 2011, 39, 183-200. [CrossRef]

14. Aligita, W.; Susilawati, E.; Sukmawati, I.K.; Holidayanti, L.; Riswanti, J. Antidiabetic activities of Muntingia calabura L. leaves water extract in type 2 diabetes mellitus animal models. Indones. Biomed. J. 2018, 10, 165-170. [CrossRef]

15. Chen, J.; Lin, R.W.; Du, C.Y.; Huang, H.Y.; Chen, I.S. Flavones and cytotoxic constituents from the stem bark of Muntingia calabura. J. Chin. Chem. Soc. 2004, 51, 665-670. [CrossRef]

16. Su, B.; Jung, E.; Schunke, J.; Graham, J.G.; Cabieses, F.; Fong, H.H.S.; Pezzuto, J.M.; Kinghorn, A.D. Activity-guided isolation of the chemical constituents of Muntingia calabura using a quinone reductase induction assay. Phytochemistry 2003, 63, 335-341. [CrossRef]

17. Zakaria, Z.A.; Nor Hazalin, N.A.M.; Zaid, S.N.H.M.; Ghani, M.A.; Hassan, M.H.; Gopalan, H.K.; Sulaiman, M.R. Antinociceptive, anti-inflammatory and antipyretic effects of Muntingia calabura aqueous extract in animal models. J. Nat. Med. 2007, 61, 443-448. [CrossRef]

18. Wu, S.Y.; Wang, G.F.; Liu, Z.Q.; Rao, J.J.; Lü, L.; Xu, W.; Wu, S.G.; Zhang, J.J. Effect of geniposide, a hypoglycemic glucoside, on hepatic regulating enzymes in diabetic mice induced by a high-fat diet and streptozotoci. Acta Pharmacol. Sin. 2009, 30, 202-208. [CrossRef] [PubMed]

19. Choi, M.S.; Jung, U.J.; Yeo, J.; Kim, M.J.; Lee, M.K. Genistein and daidzein prevent diabetes onset by elevating insulin level and altering hepatic gluconeogenic and lipogenic enzyme activities in non-obese diabetic (NOD) mice. Diabetes Metab. Res. Rev. 2008, 24, 74-81. [CrossRef]

20. Babujanarthanam, R.; Kavitha, P.; Pandian, M.R. Quercitrin, a bioflavonoid improves glucose homeostasis in streptozotocininduced diabetic tissues by altering glycolytic and gluconeogenic enzymes. Fundam. Clin. Pharmacol. 2010, 24, 357-364. [CrossRef] [PubMed] 
21. Mikell, J.R.; Herath, W.; Khan, I.A. Eleven microbial metabolites of 6-hydroxyflavanone. Chem. Pharm. Bull. 2015, 63, 579-583. [CrossRef]

22. Chandramohan, G.; Al-numair, K.S.; Alsaif, M.A.; Veeramani, C. Antidiabetic effect of kaempferol a flavonoid compound, on streptozotocin-induced diabetic rats with special reference to glycoprotein components. Prog. Nutr. 2015, $17,50-57$.

23. Vishnuvathan, V.J.; Karunanidhi, S.L.; Srividya, A.R. Medicinal uses of formononetin-A review. J. Ethnobiol. Tradit. Med. 2016, 126, 1197-1209.

24. Abu-Bakar-Sajak, A.; Abas, F.; Ismail, A.; Khatib, A. Effect of different drying treatments and solvent ratios on phytochemical constituents of Ipomoea aquatica and correlation with $\alpha$-glucosidase inhibitory activity. Int. J. Food Prop. 2016, 19, $2817-2831$. [CrossRef]

25. Singh, R.P.; Heldman, D.R. Packaging concepts. In Introduction to Food Engineering; Taylor, S.L., Ed.; Elsevier: Berkeley, CA, USA, 2013; Volume 84, pp. 745-769.

26. Mediani, A.; Abas, F.; Maulidiani, M.; Shaari, K.; Choi, Y.H.; Lajis, N.H. 1H-NMR-based metabolomics approach to understanding the drying effects on the phytochemicals in Cosmos caudatus. Food Res. Int. 2012, 49, 763-770. [CrossRef]

27. Azizan, A.; Ahamad-Bustamam, M.S.; Maulidiani, M.; Shaari, K.; Ismail, I.S.; Nagao, N.; Abas, F. Metabolite profiling of the microalgal diatom Chaetoceros alcitrans and correlation with antioxidant and nitric oxide inhibitory activities via ${ }^{1} \mathrm{H}$ NMR-based metabolomics. Mar. Drugs 2018, 16, 154. [CrossRef]

28. De-Sales, P.M.; De-Souza, P.M.; Simeoni, L.A.; Magalhães, P.D.O.; Silveira, D. $\alpha$-Amylase inhibitors: A review of raw material and isolated compounds from plant source. J. Pharm. Pharm. Sci. 2012, 15, 141-183. [CrossRef]

29. Matsui, T.; Yoshimoto, C.; Osajima, K.; Oki, T.; Osajima, Y. In vitro survey of $\alpha$-glucosidase inhibitory food components. Biosci. Biotechnol. Biochem. 1996, 60, 2019-2022. [CrossRef] [PubMed]

30. Zhang, J.; Liu, Y.; Lv, J.; Li, G. A colorimetric method for $\alpha$-glucosidase activity assay and its inhibitor screening based on aggregation of gold nanoparticles induced by specific recognition between phenylenediboronic acid and 4-aminophenyl- $\alpha$-dglucopyranoside. Nano Res. 2015, 8, 920-930. [CrossRef]

31. Keharom, S.; Mahachai, R.; Chanthai, S. The optimization study of $\alpha$-amylase activity based on central composite design-response surface methodology by dinitrosalicylic acid method. Int. Food Res. J. 2016, 23, 10-17.

32. Telagari, M.; Hullatti, K. In-vitro $\alpha$-amylase and $\alpha$-glucosidase inhibitory activity of Adiantum caudatum Linn. and Celosia argentea Linn. extracts and fractions. Indian J. Pharmacol. 2015, 47, 425-429.

33. Spigno, G.; Tramelli, L.; Faveri, D.M. De Effects of extraction time, temperature and solvent on concentration and antioxidant activity of grape marc phenolics. J. Food Eng. 2007, 81, 200-208. [CrossRef]

34. Tapani, E.; Taavitsainen, M.; Lindros, K.; Vehmas, T.; Lehtonen, E. Toxicity of ethanol in low concentrations: Experimental evaluation in cell culture. Acta Radiol. 1996, 37, 923-926. [CrossRef] [PubMed]

35. Chan, E.W.C.; Lim, Y.Y.; Wong, S.K.; Lim, K.K.; Tan, S.P.; Lianto, F.S.; Yong, M.Y. Effects of different drying methods on the antioxidant properties of leaves and tea of ginger species. Food Chem. 2009, 113, 166-172. [CrossRef]

36. Khoo, L.W.; Mediani, A.; Zolkeflee, N.K.Z.; Leong, S.W.; Ismail, I.S.; Khatib, A.; Shaari, K.; Abas, F. Phytochemical diversity of Clinacanthus nutans extracts and their bioactivity correlations elucidated by NMR based metabolomics. Phytochem. Lett. 2015, 14, 123-133. [CrossRef]

37. Lee, S.Y.; Abas, F.; Khatib, A.; Ismail, I.S.; Shaari, K.; Zawawi, N. Metabolite profiling of Neptunia oleracea and correlation with antioxidant and $\alpha$-glucosidase inhibitory activities using $1 \mathrm{H}$ NMR-based metabolomics. Phytochem. Lett. 2016, 16, 23-33. [CrossRef]

38. Nakbanpote, W.; Ruttanakorn, M.; Sukadeetad, K.; Sakkayawong, N.; Damrianant, S. Effects of drying and extraction methods on phenolic compounds and in vitro assays of Eclipta prostrata Linn. leaf extracts. Sci. Asia 2019, 45, 127-137. [CrossRef]

39. Slatnar, A.; Klancar, U.; Stampar, F.; Veberic, R. Effect of drying of figs (Ficus carica L.) on the contents of sugars, organic acids, and phenolic compounds. J. Agric. Food Chem. 2011, 59, 11696-11702. [CrossRef] [PubMed]

40. Horai, H.; Arita, M.; Kanaya, S.; Nihei, Y.; Ikeda, T.; Suwa, K.; Ojima, Y.; Tanaka, K.; Tanaka, S.; Aoshima, K.; et al. MassBank: A public repository for sharing mass spectral data for life sciences. J. Mass Spectrom. 2010, 45, 703-714. [CrossRef]

41. Kubo, I.; Yokokawa, Y. Two tyrosinase inhibiting flavonol glycosides from Buddleia coriacea. Phytochemistry 1992, 31, 1075-1077. [CrossRef]

42. Nshimo, C.M.; Pezzuto, J.M.; Kinghorn, A.D.; Farnsworth, N.R. Cytotoxic constituents of Muntingia calabura leaves and stems collected in Thailand. Int. J. Pharmacogn. 1993, 31, 77-81. [CrossRef]

43. Kim, C.S.; Koh, H.S.; Fukami, H.; Irie, R. Antifeedants of finger millet, Eleusine coracana GAERTN, against brown planthopper, Nilaparvata lugens (STÅL). Biosci. Biotechnol. Biochem. 1994, 58, 380-383. [CrossRef]

44. Yang, R.; Lan, Y.; Huang, Z.; Shao, C.; Liang, H. Isoflavonoids from Sophora tonkinensis. Chem. Nat. Compd. 2012, 48, 674-676. [CrossRef]

45. Matsuda, H.; Morikawa, T.; Xu, F.; Ninomiya, K.; Yoshikawa, M. New isoflavones and pterocarpane with hepatoprotective activity from the stems of Erycibe expansa. Planta Med. 2004, 70, 1201-1209. [CrossRef]

46. Kaneda, N.; Prezzuto, J.M.; Soejarto, D.D.; Kinghorn, A.D.; Farnsworth, N.R. Plant anticancer agents, XLVIII. New cytotoxic flavonoids from Muntingia calabura roots. J. Nat. Prod. 1991, 54, 196-206. [CrossRef]

47. Seo, E.K.; Silva, G.L.; Chai, H.B.; Chagwedra, T.E.; Farnsworth, N.R.; Cordell, G.A.; Pezzuto, J.M.; Kinghorn, A.D. Cytotoxic prenylated flavanones from Monotes engleri. Phytochemistry 1997, 45, 509-515. [CrossRef] 
48. Ingham, J.L. Systematic aspects of phytoalexin formation within tribe phaseoleae of the Leguminosae (subfamily Papilionoideae). Biochem. Syst. Ecol. 1990, 18, 329-343. [CrossRef]

49. Fukai, T.; Shen, C.B.; Horikoshi, T.; Nomura, T. Isoprenylated flavonoids from underground parts of Glycyrrhia glabra. Phytochemistry 1996, 43, 1119-1124. [CrossRef]

50. Puri, B.; Hall, A. Phytochemical Dictionary: A Handbook of Bioactive Compounds from Plants; Baxter, H., Harborne, J.B., Moss, G.P., Eds.; CRC Press: Boca Raton, FL, USA, 1998; 976p.

51. Hsu, Y.L.; Kuo, P.L.; Lin, L.T.; Lin, C.C. Isoliquiritigenin inhibits cell proliferation and induces apoptosis in human hepatoma cells. Planta Med. 2005, 71, 130-134. [CrossRef] [PubMed]

52. Morikawa, H.; Kasai, R.; Otsuka, H.; Hirata, E.; Shinzato, T.; Aramoto, M.; Takeda, Y. Terpenic and phenolic glycosides from leaves of Breynia officinalis Hemsl. Chem. Pharm. Bull. 2004, 52, 1086-1090. [CrossRef] [PubMed]

53. Zhang, B.M.; Wang, Z.B.; Xin, P.; Wang, Q.H.; Bu, H.; Kuang, H.X. Phytochemistry and pharmacology of genus Ephedra. Chin. J. Nat. Med. 2018, 16, 811-828. [CrossRef]

54. Kanchanapoom, T.; Kasai, R.; Yamasaki, K. Phenolic glycosides from Markhamia stipulata. Phytochemistry 2002, 59, 557-563. [CrossRef]

55. Liang, Z.; Yang, M.; Xu, X.; Xie, Z.; Huang, J.; Li, X.; Yang, D. Isolation and purification of geniposide, crocin-1, and geniposidic acid from the fruit of Gardenia jasminoides Ellis by high-speed counter-current chromatography. Sep. Sci. Technol. 2014, 49, 1427-1433. [CrossRef]

56. Chaudhuri, P.K.; Thakur, R.S. Narceinone, an alkaloid from Papaver somniferum. Phytochemistry 1989, 28, 2002-2003. [CrossRef]

57. Olatunde, O.O.; Della Tan, S.L.; Shiekh, K.A.; Benjakul, S.; Nirmal, N.P. Ethanolic guava leaf extracts with different chlorophyll removal processes: Anti-melanosis, antibacterial properties and the impact on qualities of Pacific white shrimp during refrigerated storage. Food Chem. 2021, 341, 128251. [CrossRef] [PubMed]

58. Fogliani, B.; Raharivelomanana, P.; Bianchini, J.P.; Bouraïma-Madjèbi, S.; Hnawia, E. Bioactive ellagitannins from Cunonia macrophylla, an endemic Cunoniaceae from New Caledonia. Phytochemistry 2005, 66, 241-247. [CrossRef]

59. Piszcz, P.; Wozniak, M.; Asztemborska, M.; Glod, B.K. Comparative analysis of antioxidative activity of flavonoids using HPLC-ED and photometric assays. Food Anal. Methods 2014, 7, 1474-1480. [CrossRef]

60. Abd-Ghafar, S.Z.; Mediani, A.; Ramli, N.S.; Abas, F. Antioxidant, $\alpha$-glucosidase, and nitric oxide inhibitory activities of Phyllanthus acidus and LC-MS/MS profile of the active extract. Food Biosci. 2018, 25, 134-140. [CrossRef]

61. Shabir, G.A. Step-by-step analytical methods validation and protocol in the quality system compliance industry. Rev. Saude Publica 2006, 40, 951-961. 